\title{
Activated Carbon-Fly Ash-Nanometal Oxide Composite Materials: Preparation, Characterization, and Tributyltin Removal Efficiency
}

\author{
Olushola S. Ayanda, ${ }^{1}$ Olalekan S. Fatoki, ${ }^{1}$ Folahan A. Adekola, ${ }^{2}$ and Bhekumusa J. Ximba' \\ ${ }^{1}$ Department of Chemistry, Faculty of Applied Sciences, Cape Peninsula University of Technology, P.O. Box 1906, \\ Bellville 7535, South Africa \\ ${ }^{2}$ Department of Chemistry, University of Ilorin, PMB 1515, Ilorin 240004, Nigeria
}

Correspondence should be addressed to Olushola S. Ayanda; osayanda@gmail.com

Received 14 July 2012; Accepted 28 August 2012

Academic Editor: Alberto Ritieni

Copyright (C) 2013 Olushola S. Ayanda et al. This is an open access article distributed under the Creative Commons Attribution License, which permits unrestricted use, distribution, and reproduction in any medium, provided the original work is properly cited.

The physicochemical properties, nature, and morphology of composite materials involving activated carbon, fly ash, $\mathrm{nFe}_{3} \mathrm{O}_{4}$, $\mathrm{nSiO}_{2}$, and $\mathrm{nZnO}$ were investigated and compared. Nature and morphology characterizations were carried out by means of scanning electron and transmission electron microscopy, X-ray diffraction, and Fourier transform infrared spectroscopy. Other physicochemical characterizations undertaken were $\mathrm{CNH}$ analysis, ash content, $\mathrm{pH}$, point of zero charge, and surface area and porosity determination by BET. Experimental results obtained revealed that activated carbon, $\mathrm{nSiO}_{2}$, activated carbon-fly ash, activated carbon-fly ash- $\mathrm{nFe}_{3} \mathrm{O}_{4}$, activated carbon-fly ash- $\mathrm{nSiO}_{2}$, and activated carbon-fly ash-nZnO composite materials exhibited net negative charge on their surfaces while fly ash, $\mathrm{nFe}_{3} \mathrm{O}_{4}$, and $\mathrm{nZnO}$ possessed net positive charge on their surfaces. Relatively higher removal efficiency ( $>99 \%$ ) of TBT was obtained for all the composite materials compared to their respective precursors except for activated carbon. These composite materials therefore offer great potential for the remediation of TBT in wastewaters.

\section{Introduction}

Fly ash, generated during the combustion of coal for energy production consists of fine, powdery particles predominantly spherical in shape, either solid or hollow, and mostly glassy (amorphous) in nature [1]. Fly ash has been proposed as a good adsorbent for NOx, SOx, and mercury removal from flue gases as well as adsorption of organic gas $[1,2]$. Fly ash has a potential application in wastewater treatment because of its major chemical components, which are alumina, silica, ferric oxide, calcium oxide, magnesium oxide, and carbon, and its physical properties such as porosity, particle size distribution, and surface area. Hence, it has been used as a low-cost adsorbent for the removal of heavy metals [36], dyes [7], phenolic compounds [8], and humic acids [9] in wastewaters. Activated carbon, on the other hand, is also widely used in a variety of areas, namely, as an adsorbent in air and water pollution control, a catalyst in the chemical and petrochemical industries, and a purifier in the food and pharmaceutical industries [10]. In the water treatment field, activated carbon is often used as an adsorbent for the removal of various synthetic and naturally occurring organic chemicals in drinking water [11]. In wastewater treatment, activated carbon is a powerful adsorbent because of its large surface area and pore volume, which allows the removal of liquid-phase contaminants, including organic compounds, heavy metal ions, and colors. Adsorption on activated carbons has been investigated extensively due to their use in many applications including the removal of toxic volatile organic compounds (VOCs) and pollutants in water and air [12-15].

Within the last few years, intensive wide spread contamination of the atmosphere and surface water related to adverse industrial operations has been of great concern and call for the development of better adsorbents. Many researchers have therefore focused on the search for better adsorbents with very high adsorption capacities, use of nanometal oxides as adsorbents, and the surface modification 
of existing adsorbents. Limited work was thus reported on the use of composite materials for wastewater treatments. Some of the reported works in this area is by Zhang et al. [10] who reported the preparation of $\mathrm{CuFe}_{2} \mathrm{O}_{4}$ /activated carbon magnetic adsorbents with mass ratio of $1: 1,1: 1.5$, and $1: 2$ for the adsorption of acid orange II (AO7) in water and subsequent separation of adsorbent from the medium by a magnetic technique. Their results suggest that the composite has much higher catalytic activity than that of activated carbon, and this is attributed to the presence of $\mathrm{CuFe}_{2} \mathrm{O}_{4}$. Shukla et al. [14] studied the synthesis of composites of carbon and natural zeolite with varying amounts of carbon as prospective adsorbents to adsorb organic contaminants from waste water such as phenol. They reported that the adsorption isotherm indicated an enhanced adsorption of phenol on the composites as compared with the natural zeolite, and that adsorption increased with increase in carbon content of the composite materials. The adsorption and degradation of trichloroethylene (TCE) through dechlorination using synthetic granular activated carbon and zerovalent iron (GAC-ZVI) composites was reported by Tseng et al. [16]. They reported that the usage of granular activated carbonzerovalent iron composites liberated a greater amount of $\mathrm{Cl}$ than when zerovalent iron was used alone. Jha et al. [17] also investigated the preparation of composite materials of activated carbon, and zeolite by activating coal fly ash by fusion and reported that the composites of activated carbon and zeolite proved to be suitable for the uptake of toxic metal ions.

Researches have therefore focused on the enhancement of the effectiveness of activated carbon and fly ash by modifying their specific properties by chemical modification (treatment with acids or bases), thermal activation, impregnation, and/or surfactant modification [18-21] in order to enable the carbon to develop affinity for certain contaminants. No work has been reported on the preparation of composite materials involving activated carbon, fly ash, $\mathrm{nFe}_{3} \mathrm{O}_{4}, \mathrm{nSiO}_{2}$, and $\mathrm{nZnO}$ as precursors, except for Fatoki et al. [22] who reported the preparation and characterization of activated carbon$n \mathrm{Fe}_{3} \mathrm{O}_{4}$, activated carbon- $\mathrm{nSiO}_{2}$, and activated carbon- $\mathrm{nZnO}$ hybrid materials. Composite materials involving activated carbon, fly ash, and nanometal oxides are expected to have high adsorption capacity due to their nature, morphology, and properties, and due to the presence of nanooxides in the composite materials; it is also expected that the remediation mechanism by these materials will combine the synergistic effect of adsorption and oxidation during the adsorption processes and not adsorption alone.

The aim of this study is, therefore, to prepare activated carbon, fly ash, and nanometal oxide composite materials capable of enhancing the adsorption of pollutants from wastewaters and to carry out a detailed characterization of these materials in order to understand the properties that will be of great importance to environmental management.

\section{Experimental}

2.1. Materials. Fly ash from Matla power station, Mpumalanga, South Africa was used in this study. Matla power station was the first of the giant $3600 \mathrm{MW}$ coal-fired power stations in South Africa and was fully operational in 1983 [23]. Activated carbon (100-400 mesh), iron (II, III), oxide nanopowder (particle size $<50 \mathrm{~nm}$ ), silica nanopowder (particle size $12 \mathrm{~nm}$ ), zinc oxide NanoGard (particle size 40-100 nm APS powder), acetic acid, hexane, sodium acetate, $\mathrm{NaBEt}_{4}$, and tributyltin chloride (TBT) were purchased from Sigma-Aldrich, USA. Sodium nitrate $\left(\mathrm{NaNO}_{3}\right)$ and potassium bromide $(\mathrm{KBr})$ were supplied by Merck, Germany, while methanol was supplied by Industrial Analytical, South Africa. Milli-Q water was used for all analytical preparations.

2.2. Preparation of Composite Materials. Activated carbon, fly ash, and nanometal oxides in the ratio $1: 1: 1$ were dispersed in $0.5 \mathrm{M} \mathrm{HCl}$ to form slurries. The slurries were stirred by means of a stirrer and evaporated to dryness in an oven. The composite materials obtained were washed with Milli-Q water, filtered, further dried in an oven at $100^{\circ} \mathrm{C}$ for 24 hours, and ground to fine powder using agate mortar and pestle $[22,24]$.

2.3. Instrumentation. FEI scanning electron microscope (Nova Nano SEM 230) and transmission electron microscope (TECNAI G $^{2} 20$ ) were used for the SEM and TEM analyses of the precursors and composite materials. Fourier transmission infrared (FTIR) absorption spectra of the precursors and composite materials were obtained by using the potassium bromide $(\mathrm{KBr})$ pellet method of sample preparation and Perkin Elmer Spectrum 1000 instrument for analysis. Euro Ea elemental analyzer was use for carbon, nitrogen, and hydrogen $(\mathrm{CNH})$ analyses. Phase identification of the precursors and activated carbon-fly ash-nanometal oxide composite materials were determined by X-ray diffractometry using a PANalytical PW 3830 diffractometer, while TriStar 3000 analyser (Micromeritics Instrument Corporation) was used for surface area and porosity determination.

2.4. $\mathrm{pH}$ and Point of Zero Charge (PZC) Determination. The $\mathrm{pH}$ was determined by gently boiling $50 \mathrm{~mL}$ of Milli-Q water in a flask containing $0.1 \mathrm{~g}$ of the samples for $5 \mathrm{mins}$. The $\mathrm{pH}$ was measured using a Mettler Toledo $\mathrm{pH}$ meter after the solution was cooled to room temperature. Mass titration technique was used to determine the PZC $[22,25]$. Increasing amounts of sample from 0 to $2 \mathrm{~g}$ were added to $10 \mathrm{~mL}$ of $0.01 \mathrm{M} \mathrm{NaNO}_{3}$ solution. The resulting $\mathrm{pH}$ of each suspension was measured after 24 hours. The $\mathrm{pH}$ plateau for the highest concentrations of solid in a successive series of mass titrations is taken as the PZC.

2.5. Ash Content Determination. Approximately $\pm 0.1 \mathrm{~g}$ of the precursors and composite materials were measured into crucibles and heated in a muffle furnace at a temperature of about $500-600^{\circ} \mathrm{C}$ for 4 hours. The samples were withdrawn from the furnace after ashing, allowed to cool in a desiccator, and then reweighed. The ash content of the precursors and composite materials was calculated by difference, and this process was carried out in triplicate. 


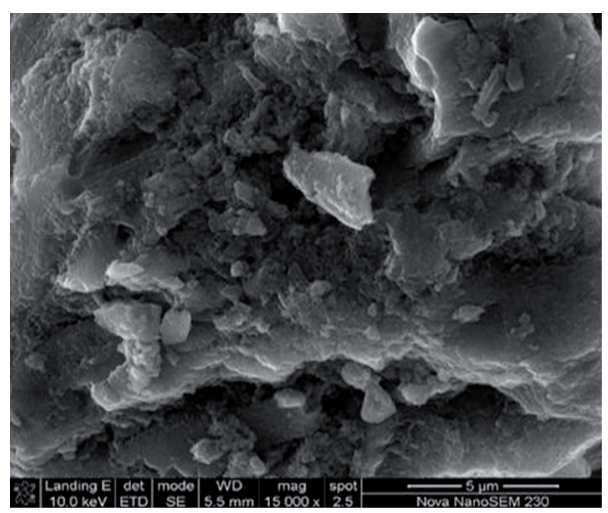

(a)

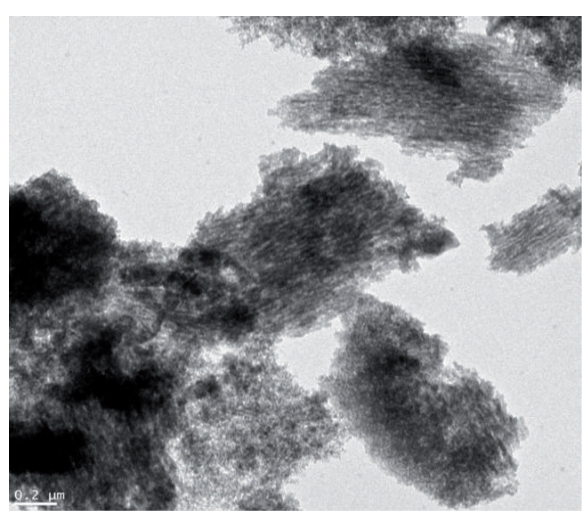

(b)

FIGURE 1: (a) SEM of activated carbon. (b) TEM of activated carbon.

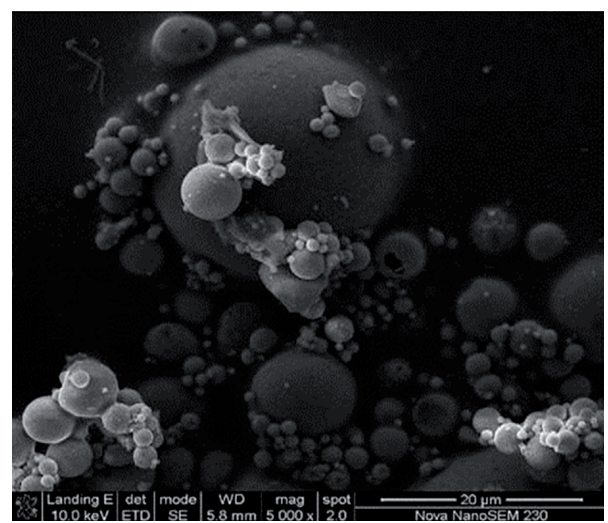

(a)

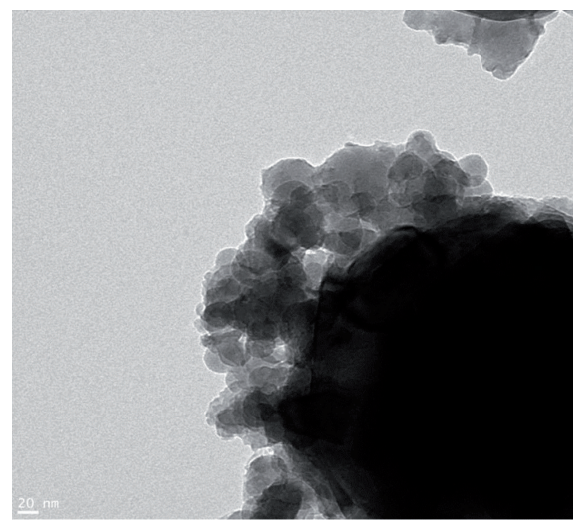

(b)

Figure 2: (a) SEM of fly ash. (b) TEM of fly ash.

2.6. TBT Removal Efficiency and Analysis. The removal efficiency of TBT by these materials was tested by applying overall optimal conditions for the adsorption of TBT from TBT-contaminated artificial seawater. The removal efficiency $(R)$ is defined as

$$
R=\left(\frac{c_{i}-c_{e}}{c_{i}}\right) \times 100,
$$

where $c_{i}$ is the initial concentration of TBT $(100 \mathrm{mg} / \mathrm{L})$ in artificial seawater placed in a conical flask and shaken at $200 \mathrm{rpm}$ for $60 \mathrm{~min}$ with $0.5 \mathrm{~g}$ of the adsorbents, and $c_{e}$ is the equilibrium solution concentration.

The concentration of TBT was determined after derivatization by the addition of $2 \mathrm{~mL}$ of acetate buffer $(\mathrm{pH}=$ 4.5 ) and $1.0 \mathrm{~mL}$ of $1 \% \mathrm{NaBEt}_{4}$ and extraction into hexane by horizontal shaking in a separation funnel. The extracts were reduced to $1 \mathrm{~mL}$ and analyzed by the use of GC-FPD (Shimadzu GC-2010 Plus) with a capillary column HP 5 (5\% phenyl methyl siloxane, $30 \mathrm{~m} \times 0.25 \mathrm{~mm}$, i.d., film thickness $0.25 \mu \mathrm{m}$ ), and the temperature was programmed as follows: initially at $60^{\circ} \mathrm{C}$ hold for $1 \mathrm{~min}$, then heated to $280^{\circ} \mathrm{C}$ at $10^{\circ} \mathrm{C} / \mathrm{min}$, and hold for $4 \mathrm{~min}$. The injection and detector temperatures were $270^{\circ} \mathrm{C}$ and $300^{\circ} \mathrm{C}$, respectively, and the carrier gas was high purity helium.

A plot of the percent removal of TBT by the various adsorbents was obtained, and the results were compared.

\section{Results and Discussion}

3.1. SEM and TEM. The scanning electron micrograph (SEM) and transmission electron micrograph (TEM) of activated carbon (Figures 1(a) and 1(b)) showed that activated carbon exhibit aggregated irregular surfaces with a large number of micropores and crevices of various sizes at the surface. The SEM and TEM of activated carbon confirmed that the activated carbon is a better adsorbent for the adsorption of pollutants from wastewaters.

Figure 2(a) showed that the particles of Matla fly ash are spherical with smooth and regular surfaces. The TEM of fly ash (Figure 2(b)) presents agglomeration of different particle sizes. The fly ash particles showed different size distributions with spherical shapes. 


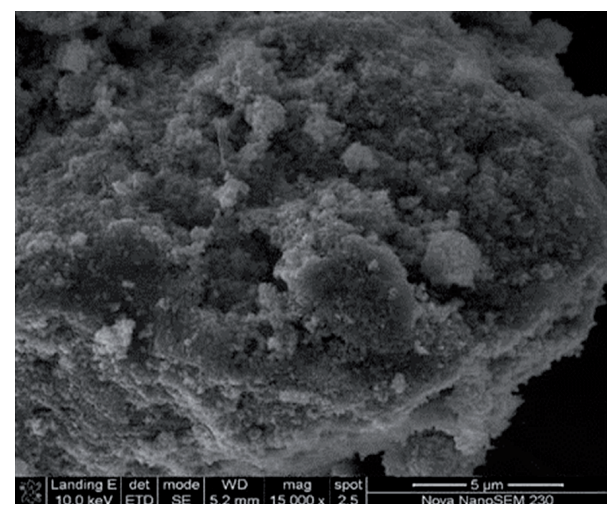

(a)

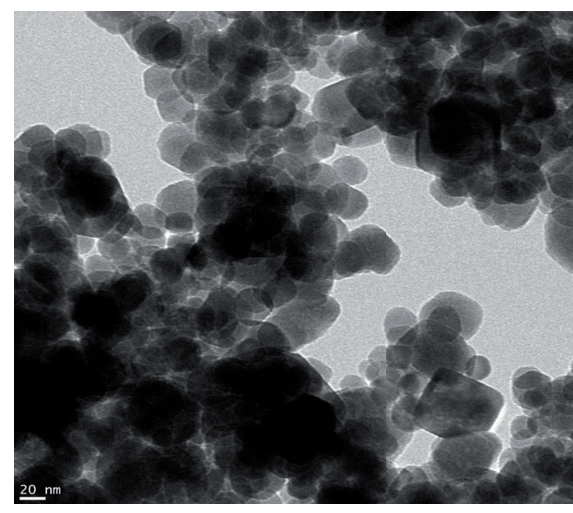

(b)

Figure 3: (a) SEM of fly $\mathrm{nFe}_{3} \mathrm{O}_{4}$. (b) $\mathrm{TEM}$ of $\mathrm{nFe}_{3} \mathrm{O}_{4}$.

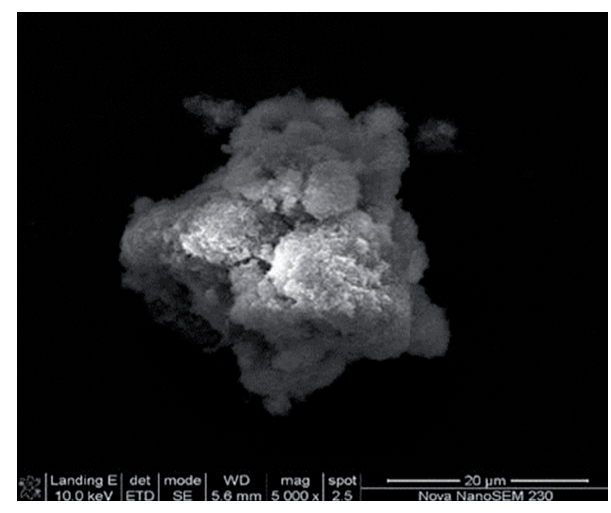

(a)

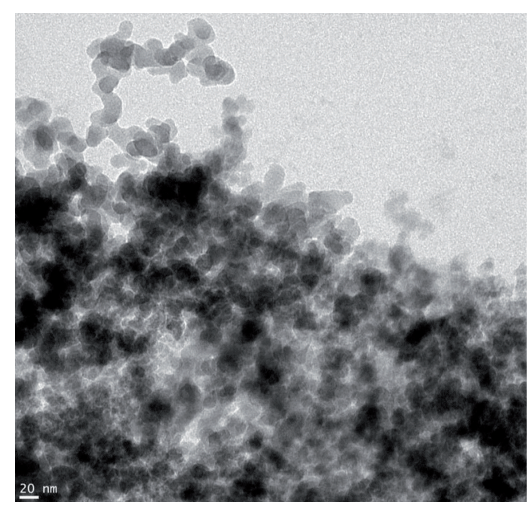

(b)

Figure 4: (a) SEM of $\mathrm{nSiO}_{2}$. (b) TEM of $\mathrm{nSiO}_{2}$.

The SEM of $\mathrm{nFe}_{3} \mathrm{O}_{4}$ (Figure 3(a)) showed that $\mathrm{nFe}_{3} \mathrm{O}_{4}$ consists of agglomerated globules with irregular and rough surfaces. The TEM of $\mathrm{nFe}_{3} \mathrm{O}_{4}$ (Figure 3(b)) presents agglomeration of particles. The TEM thus showed that $\mathrm{nFe}_{3} \mathrm{O}_{4}$ is made up of different shapes including square, spherical, and hexagonal shapes.

The SEM of $\mathrm{nSiO}_{2}$ (Figure 4(a)) showed that $\mathrm{nSiO}_{2}$ exhibit agglomerated irregular surfaces with a large number of micropores and a few voids and crevices, while the TEM of $\mathrm{nSiO}_{2}$ (Figure 4(b)) showed a bimodal distribution of particles size.

The SEM and TEM of nZnO (Figures 5(a) and 5(b)) showed that $\mathrm{nZnO}$ particles consist of nonuniform granules and more regular surfaces. The TEM of nZnO (Figure 5(b)) confirmed the various shapes and sizes of $\mathrm{nZnO}$ particles.

Figure 6(a) showed that activated carbon-fly ash composite material is made up of smooth surface materials (activated carbon) and spherical materials (fly ash) deposited at various position throughout the surfaces of the activated carbon. The TEM (Figure 6(b)) showed that the activated carbon (irregular surfaces) was aggregated with the spherical particle of fly ash.
The SEM and TEM (Figures 6(a) and 6(b)) showed that the fly ash particles maintained their spherical morphology after the preparation of activated carbon-fly ash composite material.

The SEM and TEM of activated carbon-fly ash- $\mathrm{nFe}_{3} \mathrm{O}_{4}$ composite material (Figures 7(a) and 7(b)) showed that the composite material exhibit aggregated irregular surfaces with large number of micropores and crevices at the surface. Fly ash and $\mathrm{nFe}_{3} \mathrm{O}_{4}$ were found at the surface of the activated carbon.

The SEM and TEM of activated carbon-fly ash- $\mathrm{nSiO}_{2}$ composite material (Figures $8(\mathrm{a})$ and $8(\mathrm{~b})$ ) showed that the composite material also exhibited aggregated irregular surfaces with large number of micropores and crevices at the surface. The $\mathrm{nSiO}_{2}$ and fly ash were distributed at the surface of the activated carbon.

The SEM of activated carbon-fly ash-nZnO composite material (Figure 9(a)) showed that the activated carbon, fly ash, and $\mathrm{nZnO}$ particles were fused together. Large intergranular voids and crevices were associated with the activated carbon-fly ash-nZnO composite material with fly ash still maintaining its spherical regular shape. 


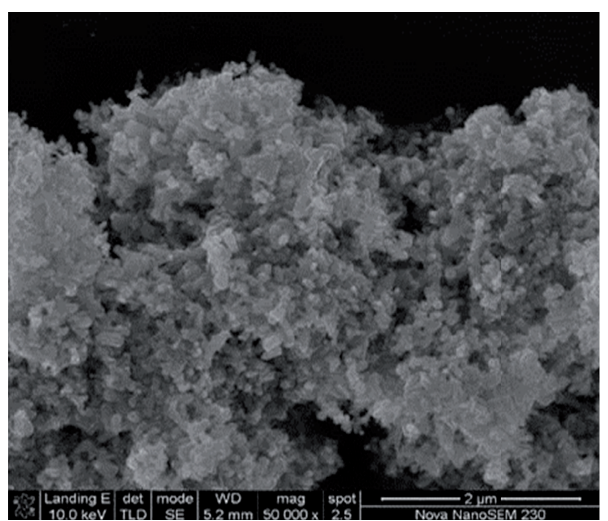

(a)

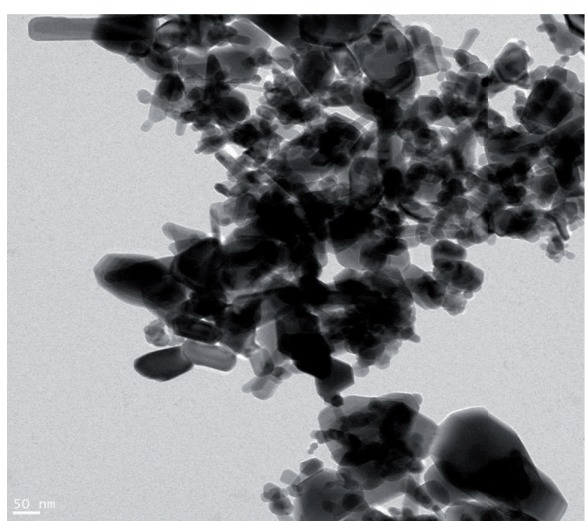

(b)

Figure 5: (a) SEM of nZnO. (b) TEM of nZnO.

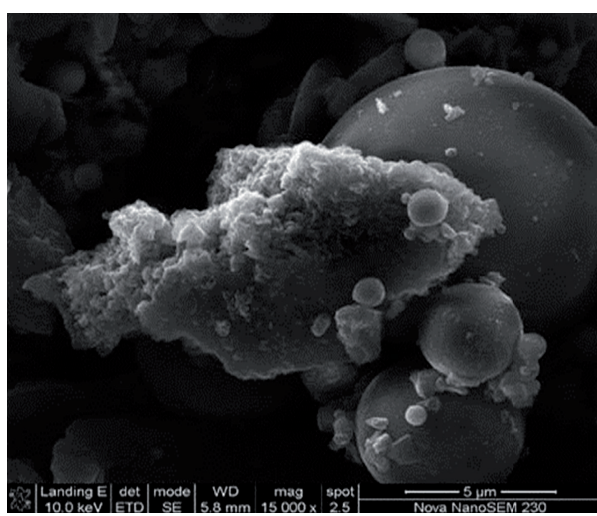

(a)

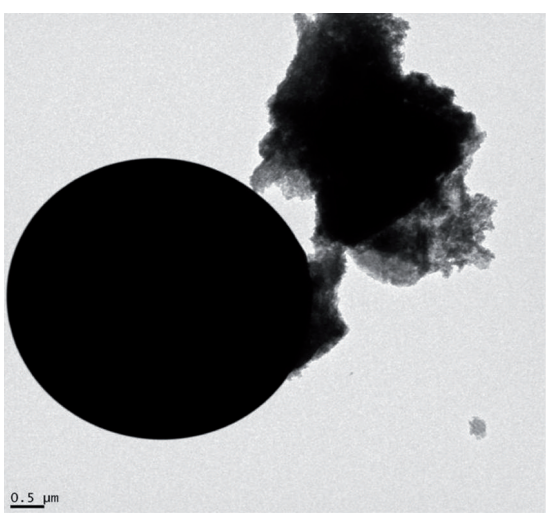

(b)

FIGURE 6: (a) SEM of activated carbon-fly ash composite material. (b) TEM of activated carbon-fly ash composite material.

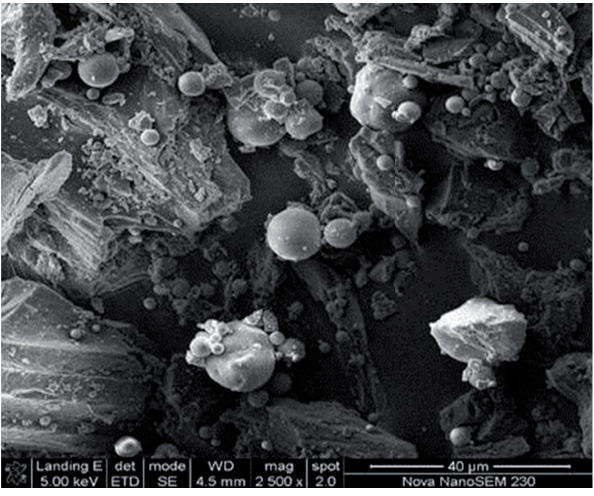

(a)

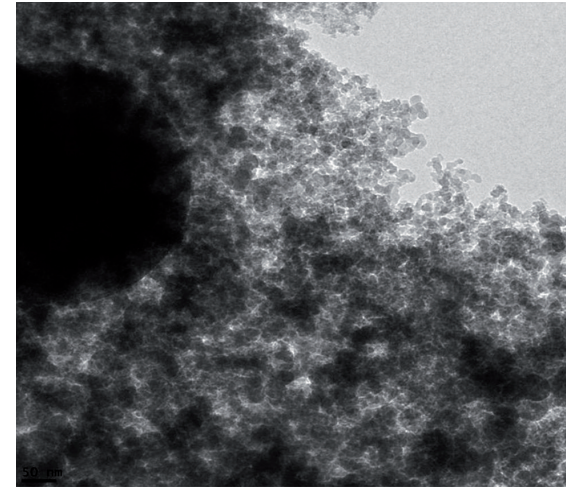

(b)

FIgURE 7: (a) SEM of activated carbon-fly ash- $\mathrm{nFe}_{3} \mathrm{O}_{4}$ composite material. (b) TEM of activated carbon-fly ash-nFe $\mathrm{O}_{4}$ composite material.

The TEM of activated carbon-fly ash-nZnO composite material (Figure 9(b)) thus showed a clustered activated carbon, fly ash, and $\mathrm{nZnO}$ composite material with large intergranular voids and crevices.
3.2. FTIR Absorption Spectra. In the FTIR spectrum of activated carbon, fly ash, and activated carbon-fly ash composite material (Figure 10), the absorption at $1616 \mathrm{~cm}^{-1}$ (curve (a)) is assigned to the $\mathrm{C}=\mathrm{C}$ stretching of activated carbon 


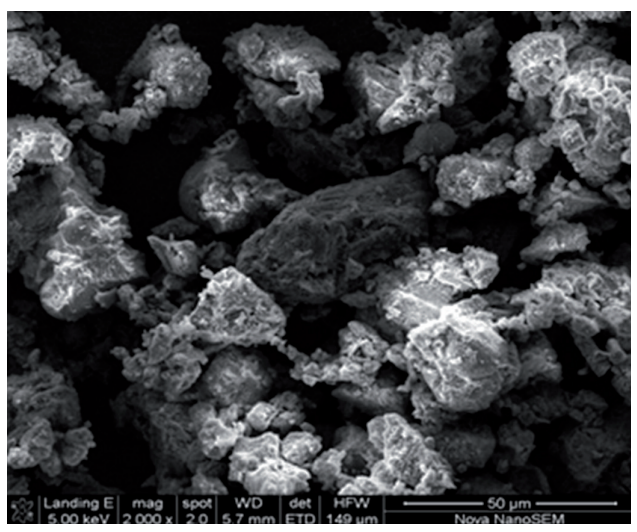

(a)

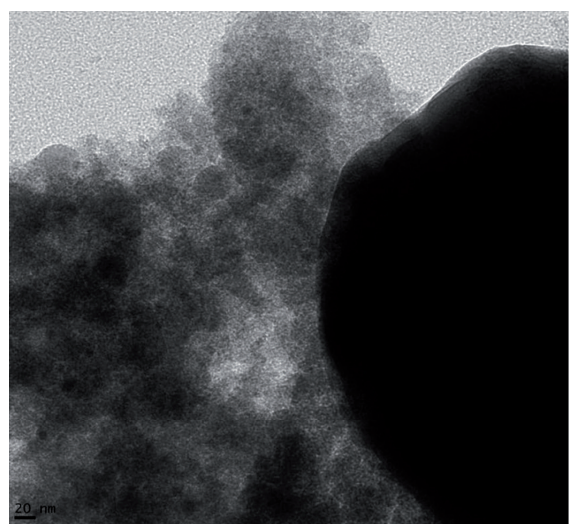

(b)

FIgURE 8: (a) SEM of activated carbon-fly ash- $\mathrm{nSiO}_{2}$ composite material. (b) TEM of activated carbon-fly ash-nSiO ${ }_{2}$ composite material.

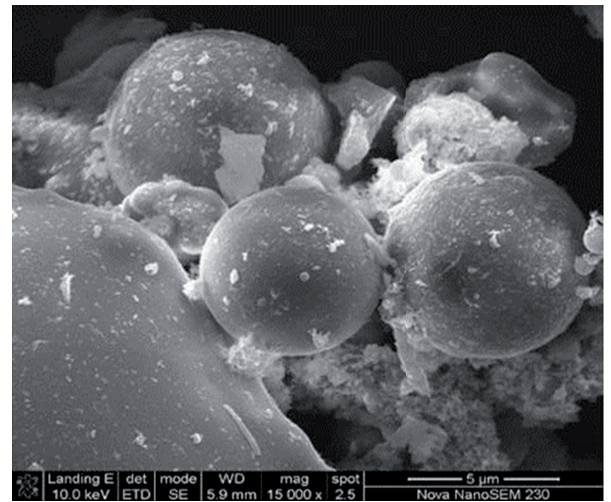

(a)

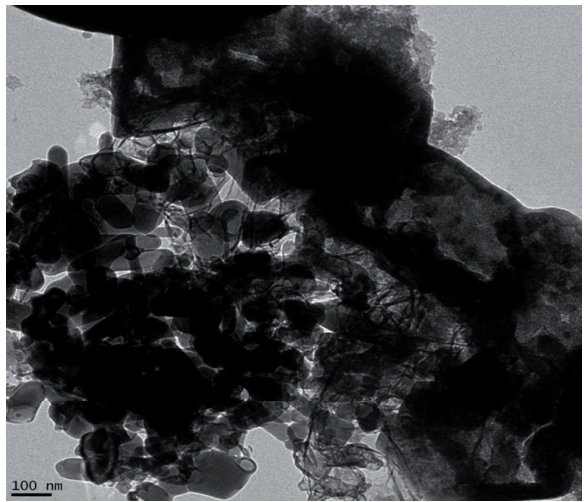

(b)

FIGURE 9: (a) SEM of activated carbon-fly ash-nZnO composite material. (b) TEM of activated carbon-fly ash-nZnO composite material.

$[26,27]$, while the absorption at $1097 \mathrm{~cm}^{-1}$ (curve (b)) is assigned to the $\mathrm{C}-\mathrm{C}$ stretching of fly ash. It was found that the wavenumber of $\mathrm{C}-\mathrm{C}$ stretching of fly ash changed slightly from $1097 \mathrm{~cm}^{-1}$ of fly ash to $1093 \mathrm{~cm}^{-1}$ (curve (f)) of the activated carbon-fly ash composite material. The wavenumber of the absorption peak decreased by $4 \mathrm{~cm}^{-1}$. The slight change in the wavenumber suggests that a new bond was formed during the preparation of the activated carbon-fly ash composite material. In the FTIR spectrum of activated carbon, fly ash, $\mathrm{nFe}_{3} \mathrm{O}_{4}$, and activated carbon-fly ash- $\mathrm{nFe}_{3} \mathrm{O}_{4}$ composite material (Figure 11), the absorption at $1616 \mathrm{~cm}^{-1}$ (curve (a)) is assigned to the $\mathrm{C}=\mathrm{C}$ stretching of activated carbon, and the absorption at $1097 \mathrm{~cm}^{-1}$ (curve (b)) is assigned to the $\mathrm{C}-\mathrm{C}$ stretching of fly ash, while the absorption at $586 \mathrm{~cm}^{-1}$ (curve (c)) is assigned to the $\mathrm{Fe}-\mathrm{O}$ stretching of $\mathrm{nFe}_{3} \mathrm{O}_{4}$. It was found that the wavenumber of $\mathrm{Fe}-\mathrm{O}$ stretching changed from $586 \mathrm{~cm}^{-1}$ of $\mathrm{nFe}_{3} \mathrm{O}_{4}$ to $560 \mathrm{~cm}^{-1}$ (curve $(\mathrm{g})$ ) of the activated carbon-fly ash- $\mathrm{nFe}_{3} \mathrm{O}_{4}$ composite material. The wavenumber of the absorption peak decreased by $26 \mathrm{~cm}^{-1}$. Decrease in the wavenumber suggests

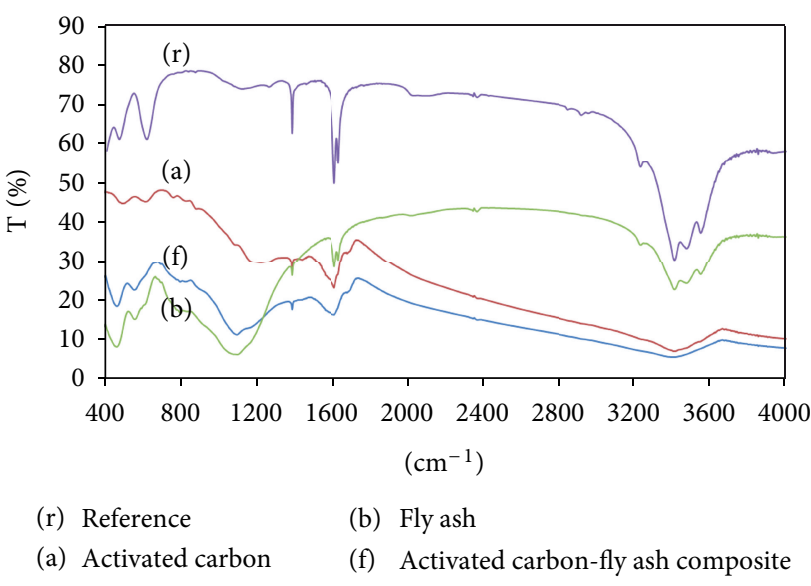

FIGURE 10: FTIR spectrum of precursors and activated carbon-fly ash composite material.

that a new bond was formed during the preparation of the activated carbon-fly ash- $\mathrm{nFe}_{3} \mathrm{O}_{4}$ composite material. 


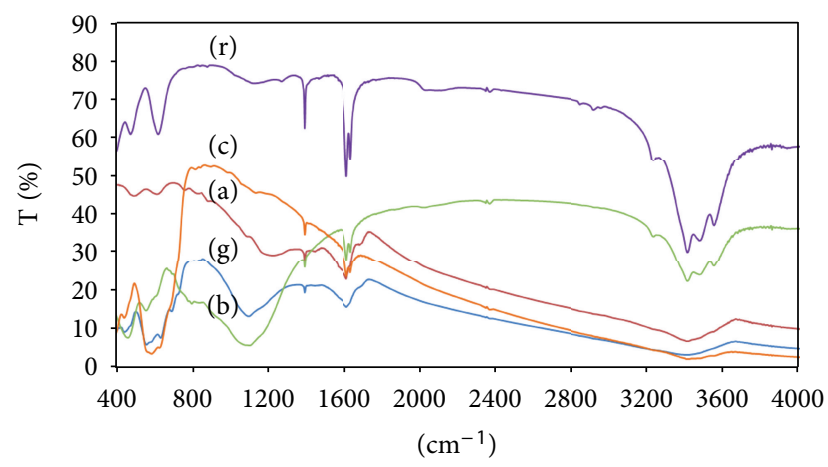

(r) Reference

(a) Activated carbon

(b) Fly ash

(c) $\mathrm{nFe}_{3} \mathrm{O}_{4}$

(g) Activated carbon-fly ash-nFe $\mathrm{O}_{4}$ composite

FIGURE 11: FTIR spectrum of precursors and activated carbon-fly ash- $\mathrm{nFe}_{3} \mathrm{O}_{4}$ composite material.

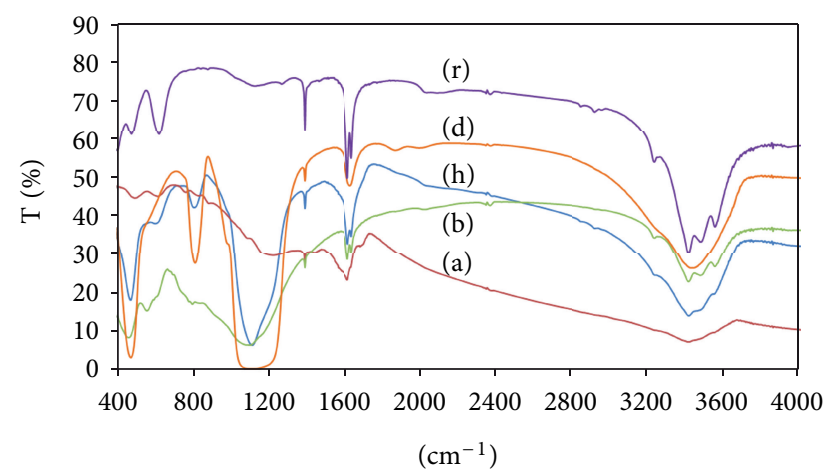
(r) Reference
(d) $\mathrm{nSiO}_{2}$
(a) Activated carbon
(b) Fly ash
(h) Activated carbon-fly ash- $\mathrm{NSiO}_{2}$ composite

FIGURE 12: FTIR spectrum of precursors and activated carbon-fly ash- $\mathrm{nSiO}_{2}$ composite material.

In the FTIR spectrum of activated carbon, fly ash, $\mathrm{nSiO}_{2}$, and activated carbon-fly ash- $\mathrm{nSiO}_{2}$ composite material (Figure 12), the absorption at $1616 \mathrm{~cm}^{-1}$ (curve (a)) is assigned to the $\mathrm{C}=\mathrm{C}$ stretching of activated carbon, and the absorption at $1097 \mathrm{~cm}^{-1}$ (curve (b)) is assigned to the $\mathrm{C}-\mathrm{C}$ stretching of fly ash, while the absorption at $1101 \mathrm{~cm}^{-1}$ (curve (d)) is assigned to the asymmetric vibration of $\mathrm{Si}-\mathrm{O}$. The absorption at $809 \mathrm{~cm}^{-1}$ (curve (d)) is assigned to the symmetric vibration of $\mathrm{Si}-\mathrm{O}$ [28]. It was found that the wavenumber of the symmetric vibration of $\mathrm{Si}-\mathrm{O}$ changed from $809 \mathrm{~cm}^{-1}$ of $\mathrm{nSiO}_{2}$ to $805 \mathrm{~cm}^{-1}$ (curve (h)) of the activated carbon-fly ash- $\mathrm{nSiO}_{2}$ composite material. The wavenumber of the absorption peak decreased by $4 \mathrm{~cm}^{-1}$. A decrease in the wavenumber suggests that a new bond was formed during the preparation of the activated carbon-fly ash-nSiO ${ }_{2}$ composite material.

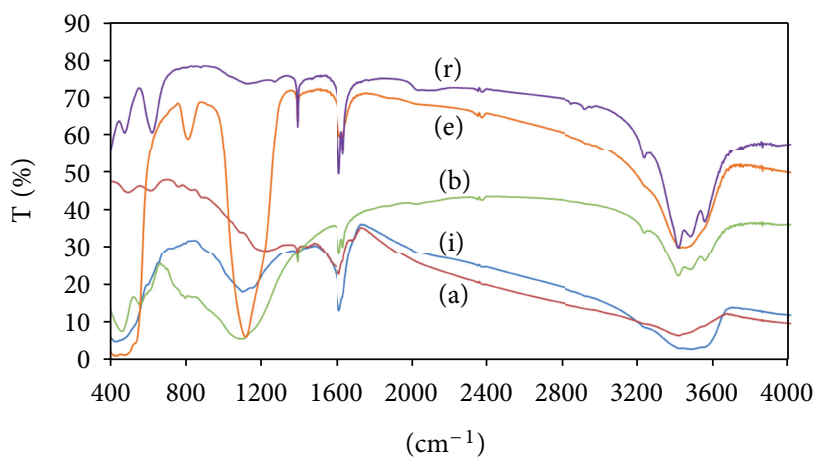

(r) Reference
(a) Activated carbon
(b) Fly ash

(e) $\mathrm{nZnO}$

(h) Activated carbon-fly ash-nZnO composite

FIGURE 13: FTIR spectrum of precursors and activated carbon-fly ash-nZnO composite material.

In the FTIR spectrum of activated carbon, fly ash, $\mathrm{nZnO}$, and activated carbon-fly ash-nZnO composite material (Figure 13), the absorption at $1616 \mathrm{~cm}^{-1}$ (curve (a)) is assigned to the $\mathrm{C}=\mathrm{C}$ stretching of activated carbon, and the absorption at $1097 \mathrm{~cm}^{-1}$ (curve (b)) is assigned to the C-C stretching of fly ash, while the absorption at $1110 \mathrm{~cm}^{-1}$ (curve (e)) is assigned to the asymmetry vibration of $\mathrm{Zn}-\mathrm{O}$, and the absorption at $808 \mathrm{~cm}^{-1}$ (curve (e)) is assigned to the $\mathrm{Zn}-\mathrm{O}$ stretching of $\mathrm{nZnO}$. It was found that the wavenumber of $\mathrm{Zn}-\mathrm{O}$ vibration changed from $1110 \mathrm{~cm}^{-1}$ of $\mathrm{nZnO}$ to $1094 \mathrm{~cm}^{-1}$ (curve (i)) of the activated carbon-fly ash-nZnO composite material. The wavenumber of the absorption peak decreased by $16 \mathrm{~cm}^{-1}$. Decrease in the wavenumber suggests that a new bond was formed during the preparation of the activated carbon-fly ash-nZnO composite material.

The result obtained thus shows that the shift in the band is a function of the metal ions present in the composite materials. The FTIR data also confirm the absence of impurity in both the precursors and the prepared composite materials.

3.3. Carbon, Nitrogen, and Hydrogen Content. Figure 14 showed that the activated carbon-fly ash- $\mathrm{nFe}_{3} \mathrm{O}_{4}$, activated carbon-fly ash-nSiO ${ }_{2}$, activated carbon-fly ash-nZnO, and activated carbon-fly ash composite materials contained $29.34 \%, 34.04 \%, 30.69 \%$, and $36.83 \%$ carbon content, respectively. Values of $0.91 \%, 0.26 \%$, and $0.20 \%$ were recorded for the nitrogen content of activated carbon-fly ash- $\mathrm{nFe}_{3} \mathrm{O}_{4}$, activated carbon-fly ash-nSiO${ }_{2}$, and activated carbon-fly ash$\mathrm{nZnO}$, respectively, while the nitrogen content of activated carbon-fly ash composite material was below the detection limit. The activated carbon-fly ash, activated carbon-fly ash- $\mathrm{nFe}_{3} \mathrm{O}_{4}$, activated carbon-fly ash- $\mathrm{nSiO}_{2}$, and activated carbon-fly ash-ZnO thus contained $2.72 \%, 2.24 \%, 0.51 \%$, and $0.89 \%$ hydrogen contents, respectively.

The result showed that the carbon content of activated carbon plays a dominant role in the carbon content of all the composite materials. 


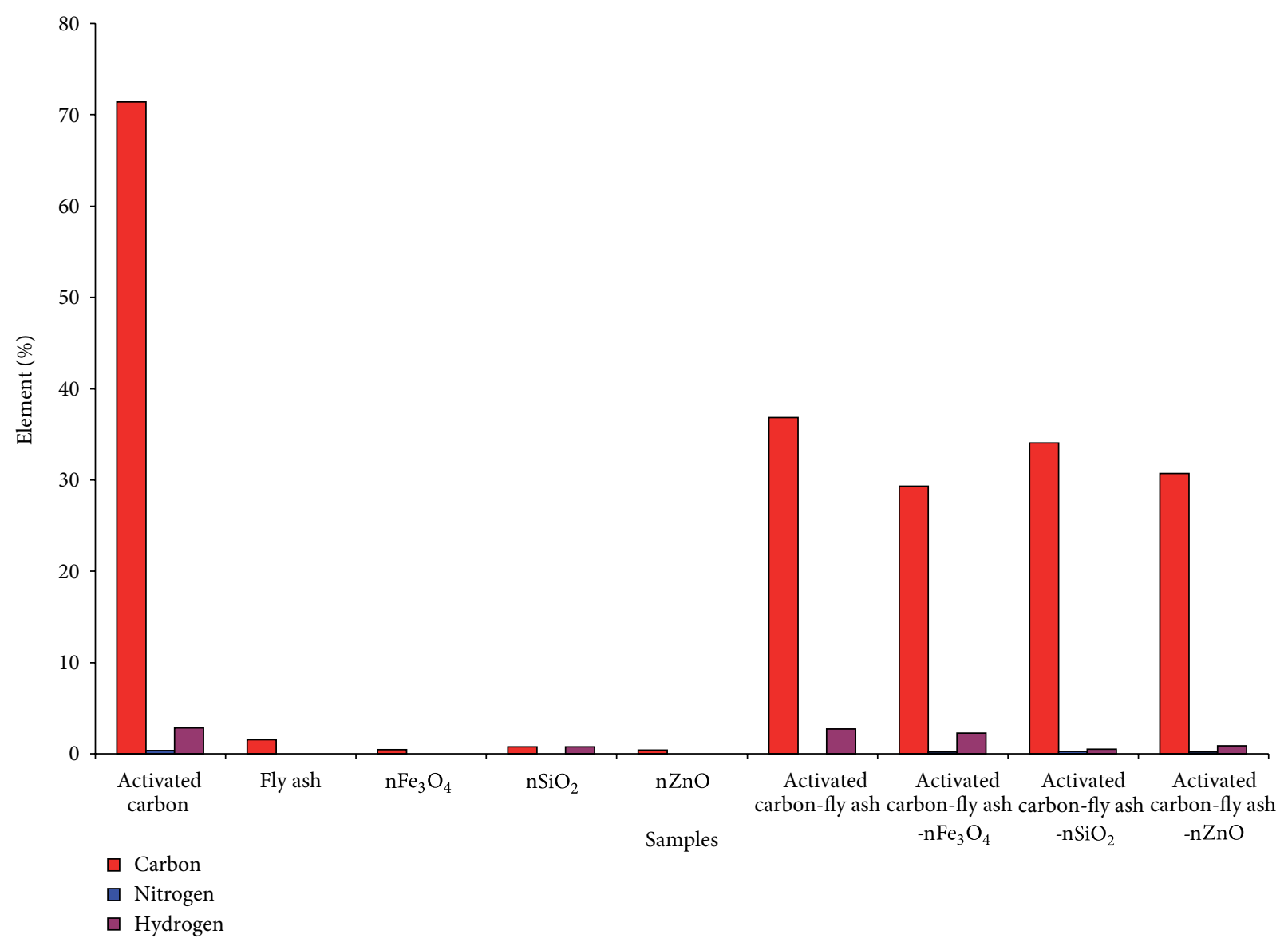

FIGURE 14: A plot of element (\%) against the precursors and composite materials.

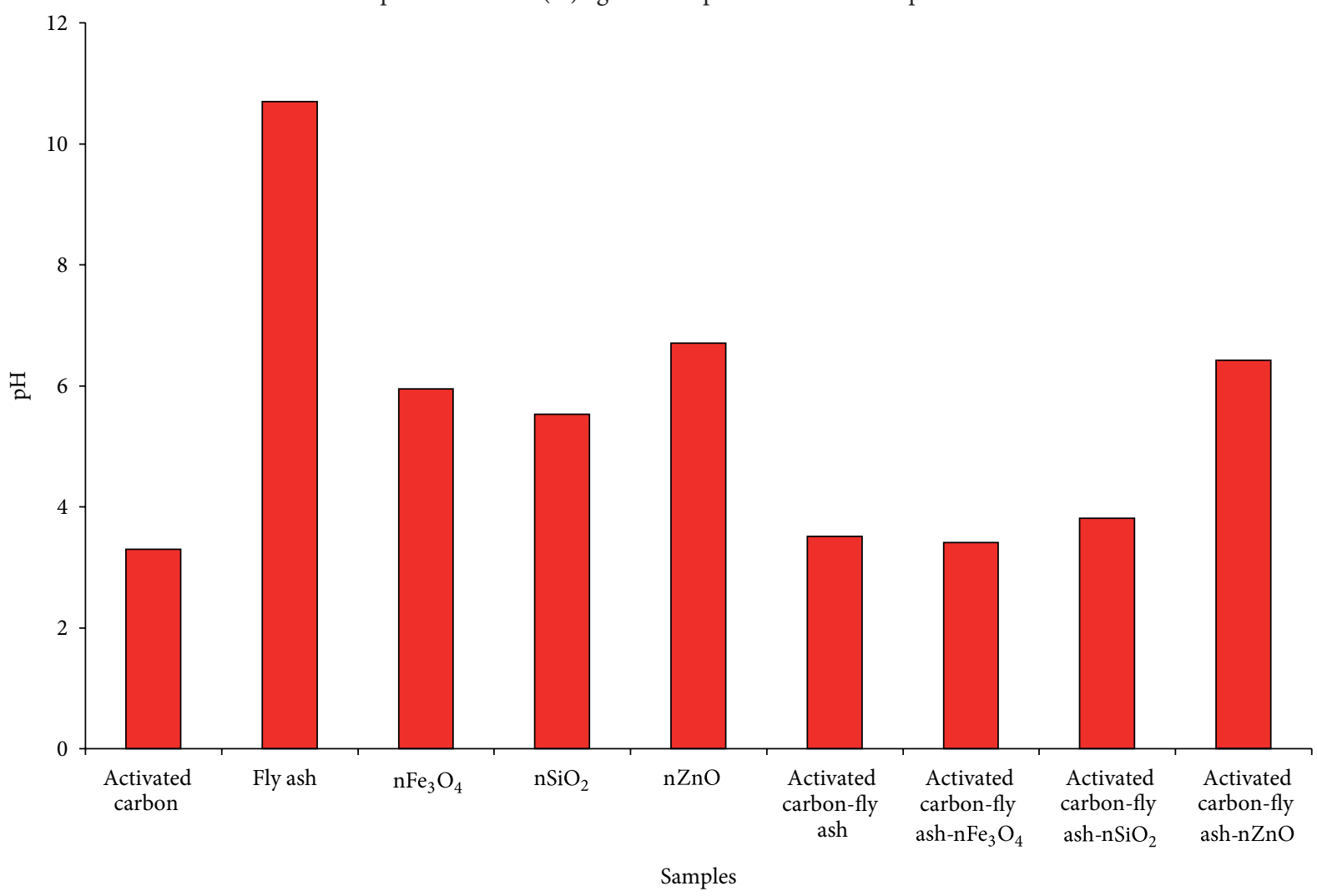

FIGURE 15: pH of activated carbon, fly ash, nano metal oxides, and composite materials. 


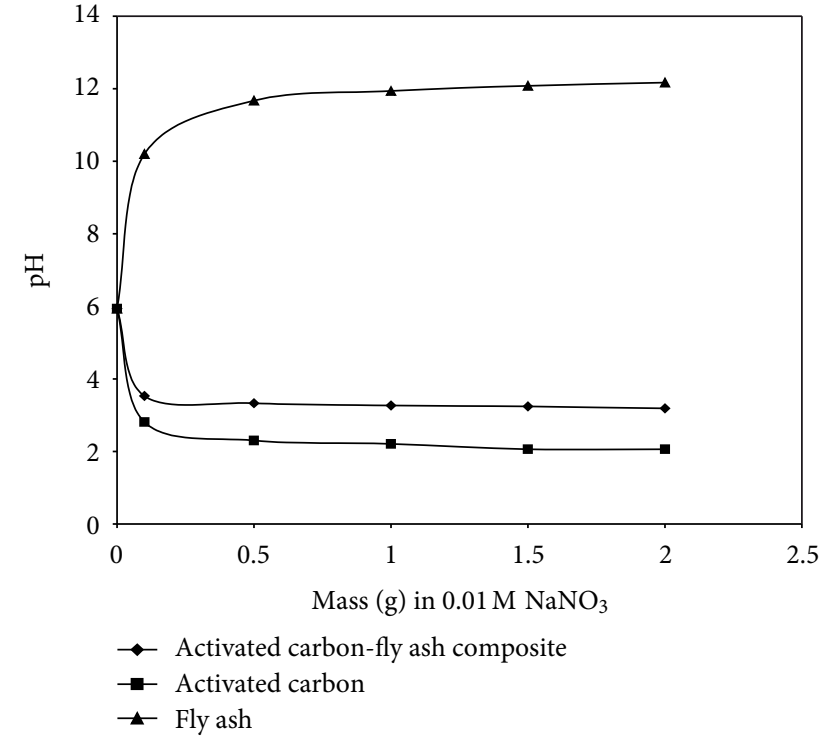

FIGURE 16: Result of mass titration experiments with activated carbon, fly ash, and activated carbon-fly ash composite material. Variation of $\mathrm{pH}$ versus mass of solid in $0.01 \mathrm{M} \mathrm{NaNO}_{3}$.

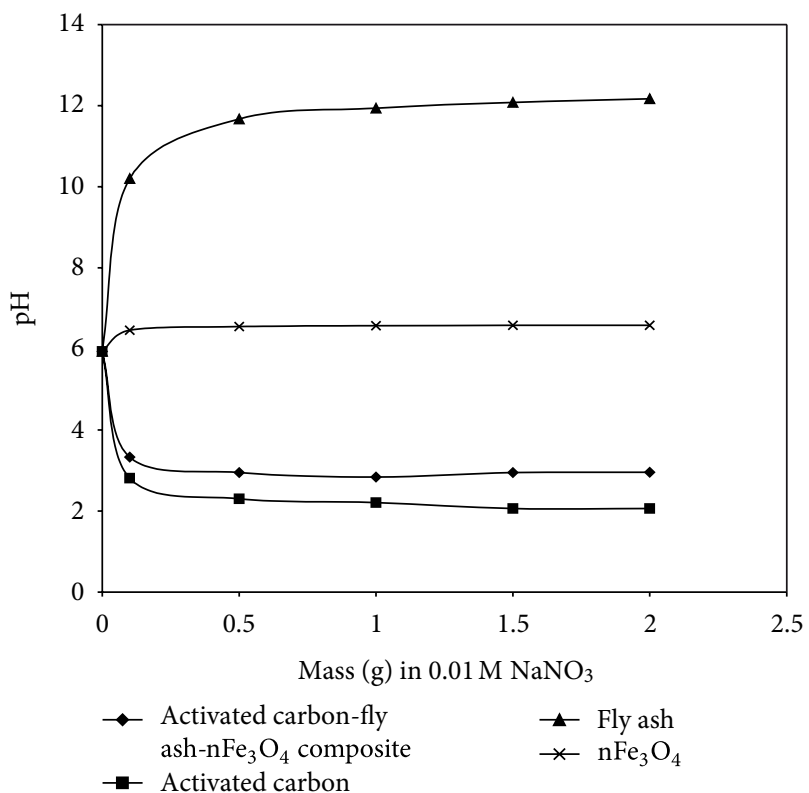

FIGURE 17: Result of mass titration experiments with activated carbon, fly ash, $\mathrm{nFe}_{3} \mathrm{O}_{4}$, and activated carbon-fly ash- $\mathrm{nFe}_{3} \mathrm{O}_{4}$ composite material. Variation of $\mathrm{pH}$ versus mass of solid in $0.01 \mathrm{M} \mathrm{NaNO}_{3}$.

3.4. $\mathrm{pH}$ and Point of Zero Charge (PZC) Measurement. From Figure 15, the preparation of activated carbon-fly ash composite material using activated carbon $(\mathrm{pH} 3.3)$ and fly ash ( $\mathrm{pH}$ 10.70) as precursors resulted in activated carbonfly ash composite material of $\mathrm{pH} 3.51$. The $\mathrm{pH}$ was higher than the $\mathrm{pH}$ of activated carbon by $59.8 \%$ and lower than the $\mathrm{pH}$ of fly ash by $67.2 \%$. The preparation of activated carbon-fly ash-nFe $\mathrm{O}_{4}$ composite material using activated

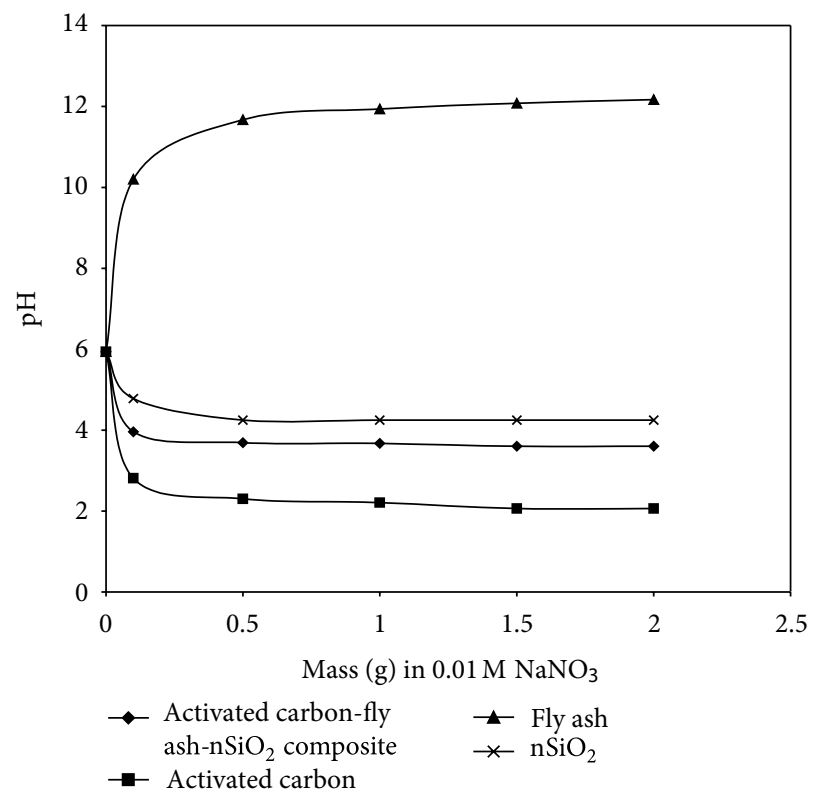

FIGURE 18: Result of mass titration experiments with activated carbon, fly ash, $\mathrm{nSiO}_{2}$ and activated carbon-fly ash- $\mathrm{nSiO}_{2}$ composite material. Variation of $\mathrm{pH}$ versus mass of solid in $0.01 \mathrm{M} \mathrm{NaNO}_{3}$.

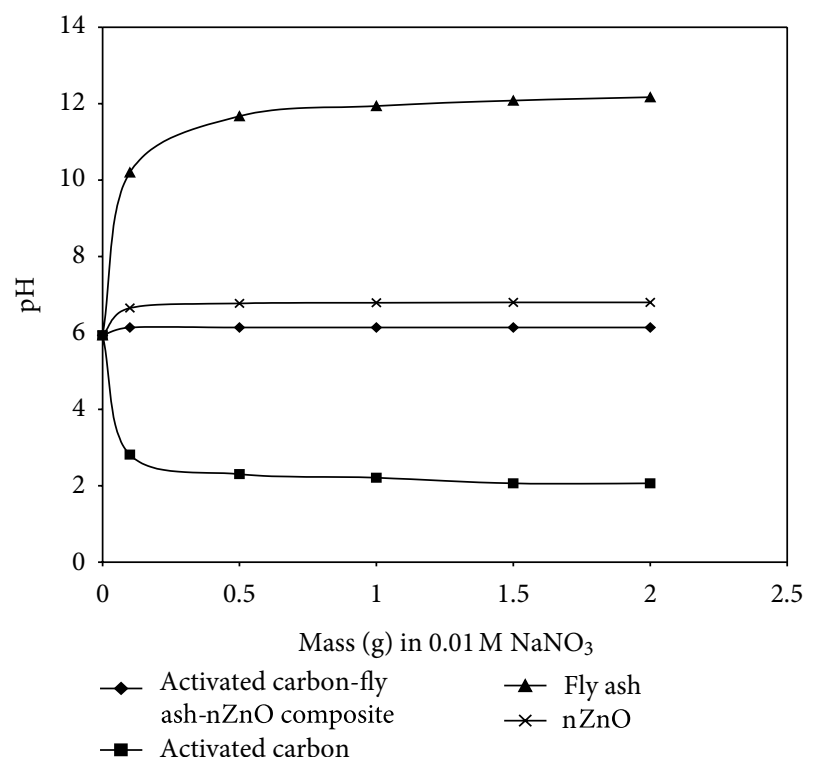

FIGURE 19: Result of mass titration experiments with activated carbon, fly ash, $\mathrm{nZnO}$, and activated carbon-fly ash-nZnO composite material. Variation of $\mathrm{pH}$ versus mass of solid in $0.01 \mathrm{M} \mathrm{NaNO}_{3}$.

carbon ( $\mathrm{pH} 3.3$ ), fly ash ( $\mathrm{pH} 10.70)$, and $\mathrm{nFe}_{3} \mathrm{O}_{4}(\mathrm{pH} 5.95)$ as precursors resulted to activated carbon-fly ash-nFe $\mathrm{O}_{4}$ composite material of $\mathrm{pH} 3.41$. The $\mathrm{pH}$ was higher than $\mathrm{pH}$ of activated carbon by $32.3 \%$, lower than $\mathrm{pH}$ of fly ash by $68.1 \%$, and lower than $\mathrm{pH}$ of $\mathrm{nFe}_{3} \mathrm{O}_{4}$ by $42.7 \%$.

The preparation of activated carbon-fly ash- $\mathrm{nSiO}_{2} \mathrm{com}-$ posite material using activated carbon ( $\mathrm{pH} 3.3$ ), fly ash ( $\mathrm{pH} 10.70)$, and $\mathrm{nSiO}_{2}(\mathrm{pH}$ 5.53) as precursors resulted in 


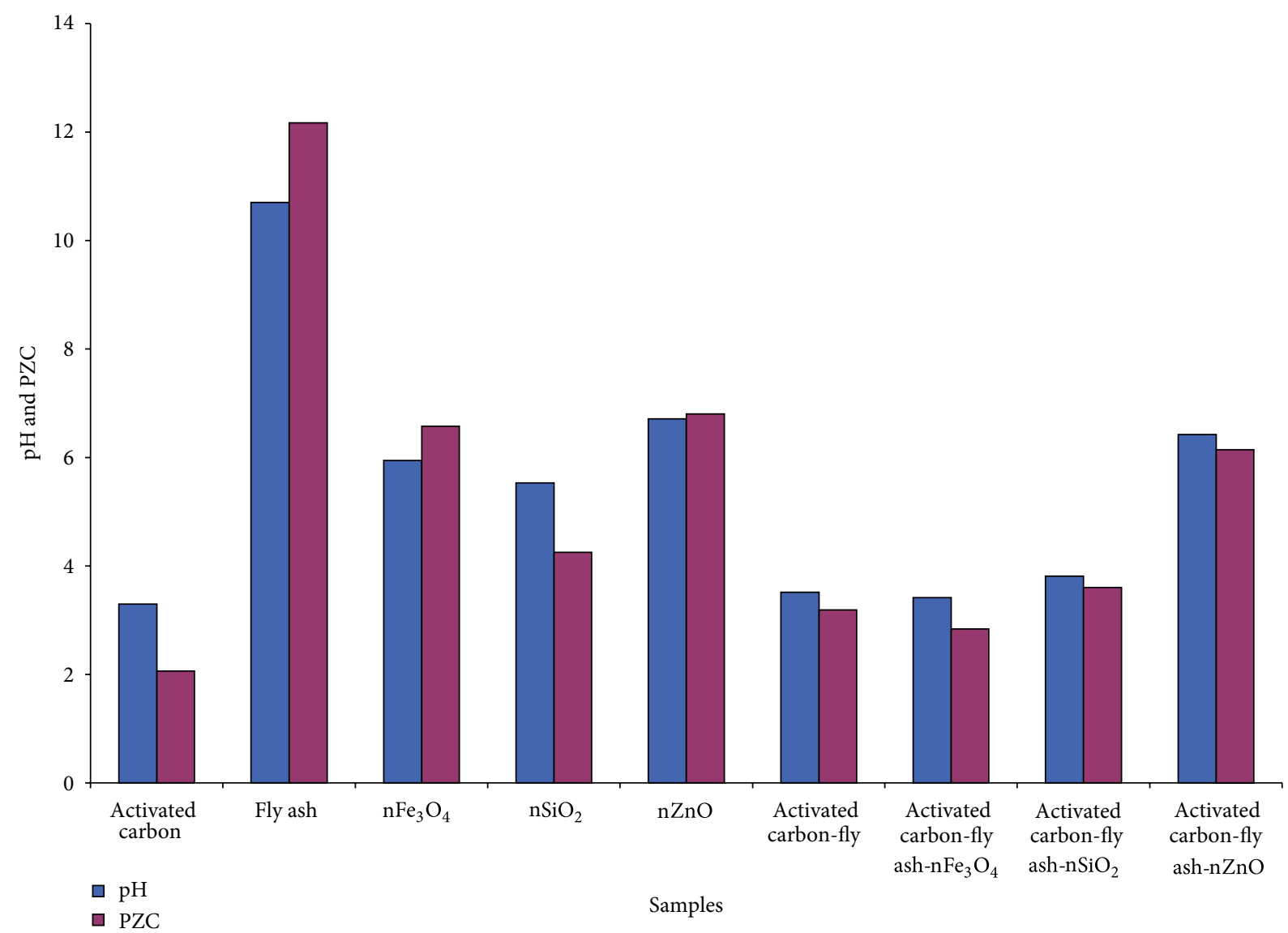

FIGURE 20: pH and PZC of activated carbon, fly ash, nanometal oxides, and composite materials.

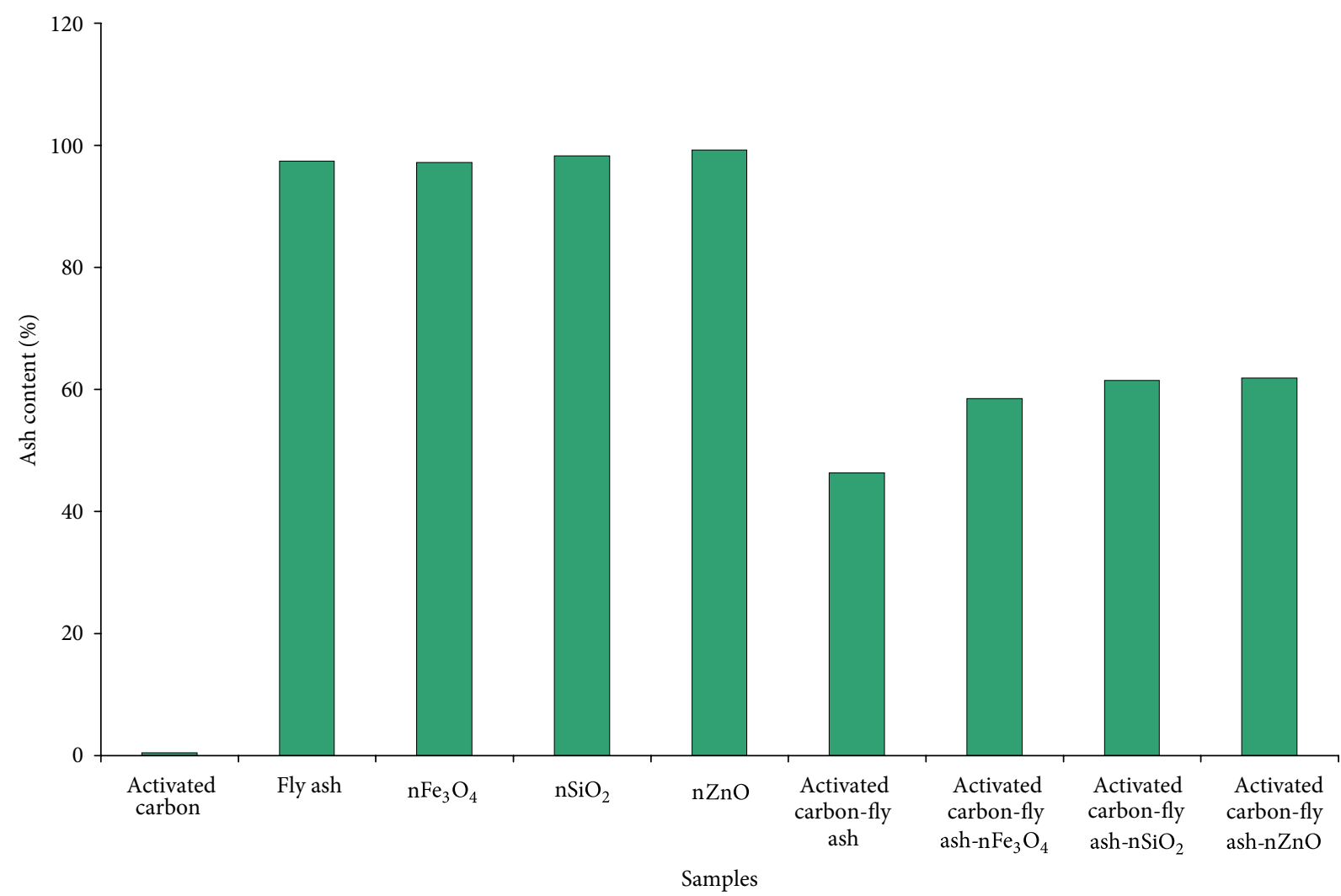

FIGURE 21: Ash content (\%) versus activated carbon, fly ash, nanoparticles, and composite materials. 
activated carbon-fly ash-nSiO ${ }_{2}$ composite material of $\mathrm{pH}$ 3.34. The $\mathrm{pH}$ was higher than $\mathrm{pH}$ of activated carbon by $1.2 \%$, lower than $\mathrm{pH}$ of fly ash by $68.8 \%$, and lower than $\mathrm{pH}$ of $\mathrm{nSiO}_{2}$ by $39.6 \%$. The preparation of activated carbon-fly ash$\mathrm{nZnO}$ composite material using activated carbon ( $\mathrm{pH} 3.3$ ), fly ash $(\mathrm{pH} 10.70)$, and $\mathrm{nZnO}(6.71)$ as precursors resulted to activated carbon-fly ash-nZnO composite material of $\mathrm{pH}$ 6.42. The $\mathrm{pH}$ was higher than $\mathrm{pH}$ of activated carbon by $48.6 \%$, lower than $\mathrm{pH}$ of fly ash by $40.0 \%$, and lower than $\mathrm{pH}$ of $\mathrm{nZnO}$ by $4.3 \%$. The result obtained shows that the $\mathrm{pH}$ values of the composite materials were determined by the $\mathrm{pH}$ value of each of the precursors that made up the composite materials.

Figure 16 showed that the point of zero charge (PZC) of activated carbon, fly ash, and activated carbon-fly ash composite material are 2.06, 12.17, and 3.19, respectively. The PZC of activated carbon-fly ash composite material was higher than PZC of activated carbon by $35.42 \%$, but lower than the PZC of fly ash by $73.79 \%$. The graph showed that the presence of fly ash (high PZC value and basic) in the activated carbon (acidic) raised the PZC of activated carbon to form activated carbon-fly ash composite material of PZC of 3.19.

Figure 17 showed that the PZC of activated carbon, fly ash, $\mathrm{nFe}_{3} \mathrm{O}_{4}$, and activated carbon-fly ash- $\mathrm{nFe}_{3} \mathrm{O}_{4}$ composite material are $2.06,12.17,6.58$, and 2.84 , respectively. The PZC of activated carbon-fly ash- $\mathrm{nFe}_{3} \mathrm{O}_{4}$ composite material was higher than the PZC of activated carbon by $27.46 \%$, lower than PZC of fly ash by $76.66 \%$, and also lower than the PZC of $\mathrm{nFe}_{3} \mathrm{O}_{4}$ by $56.84 \%$.

From Figure 18, the PZC of activated carbon, fly ash, $\mathrm{nSiO}{ }_{2}$, and activated carbon-fly ash- $\mathrm{nSiO}_{2}$ composite material are $2.06,12.17,4.25$, and 3.60 , respectively. The PZC of activated carbon-fly ash- $\mathrm{nSiO}_{2}$ composite material was therefore higher than the PZC of activated carbon by $42.78 \%$, lower than PZC of fly ash by $70.42 \%$, and also lower than the $\mathrm{PZC}$ of $\mathrm{nSiO}_{2}$ by $15.29 \%$.

From Figure 19, the PZC of activated carbon, fly ash, $\mathrm{nZnO}$, and activated carbon-fly ash-nZnO composite material are $2.06,12.17,6.80$, and 6.14 , respectively. The PZC of activated carbon-fly ash-nZnO composite material was therefore higher than the PZC of activated carbon by $66.45 \%$, lower than PZC of fly ash by $49.55 \%$, and also lower than the PZC of $n Z n O$ by $9.71 \%$.

Comparing the PZC values of the precursors and the composite materials, it could be concluded that it is not the presence of the nanoparticles alone that determines the PZC changes, but the PZC of each of the component precursors that made up the composite materials.

Figure 20 thus showed that the $\mathrm{pH}$ values of activated carbon, $\mathrm{nSiO}_{2}$, activated carbon-fly ash, activated carbon-fly ash-nFe $\mathrm{O}_{4}$, activated carbon-fly ash-nSiO${ }_{2}$, and activated carbon-fly ash-nZnO were slightly higher than their corresponding PZC values. This suggests that the surface of these materials is negatively charged and will therefore attract cations. The $\mathrm{pH}$ values of fly ash, $\mathrm{nFe}_{3} \mathrm{O}_{4}$, and $\mathrm{nZnO}$ are slightly lower than their corresponding PZC values, hence, their surface is positively charged and will attract anions.

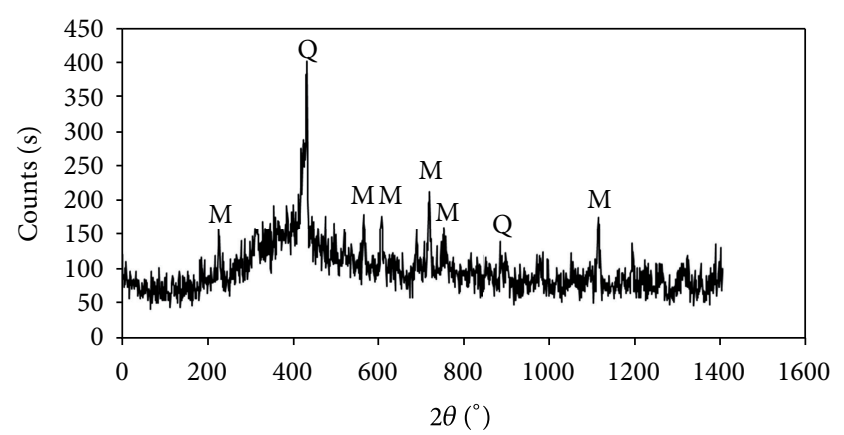

M: Mullite $\left(\mathrm{Al}_{6} \mathrm{Si}_{2} \mathrm{O}_{13}\right)$

Q: Quartz $\left(\mathrm{SiO}_{2}\right)$

FIGURE 22: X-ray diffraction of activated carbon-fly ash composite material.

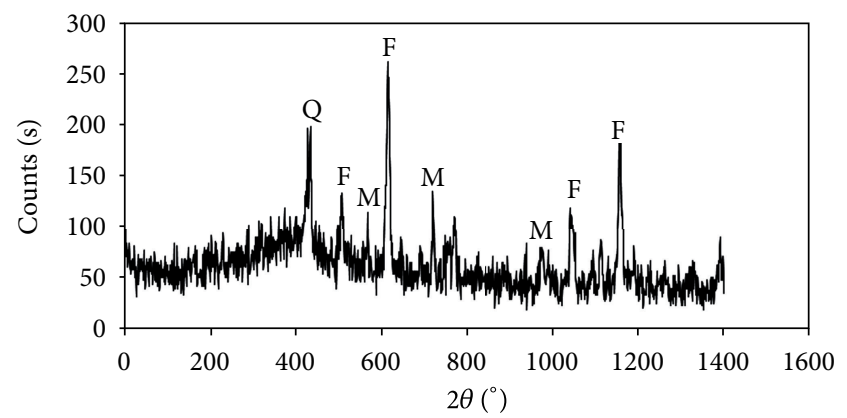
M: Mullite $\left(\mathrm{Al}_{6} \mathrm{Si}_{2} \mathrm{O}_{13}\right)$
Q: Quartz $\left(\mathrm{SiO}_{2}\right)$
F: Magnetite $\left(\mathrm{Fe}_{3} \mathrm{O}_{4}\right)$

FIGURE 23: X-ray diffraction of activated carbon-fly ash- $\mathrm{nFe}_{3} \mathrm{O}_{4}$ composite material.

3.5. Ash Content. Figure 21 showed that the ash content of the activated carbon, fly ash, $\mathrm{nFe}_{3} \mathrm{O}_{4}, \mathrm{nSiO}_{2}$, and $\mathrm{nZnO}$ is $0.45 \pm$ $0.07 \%, 97.4 \pm 0.14 \%, 97.2 \pm 0.02 \%, 98.3 \pm 0.07 \%$, and $99.2 \pm$ $0.14 \%$, respectively, while $46.3 \pm 0.14 \%, 58.5 \pm 0.12 \%, 61.45$ $\pm 0.07 \%$, and $61.9 \pm 0.14 \%$ were recorded as the ash contents of activated carbon-fly ash, activated carbon-fly ash- $\mathrm{nFe}_{3} \mathrm{O}_{4}$, activated carbon-fly ash-nSiO ${ }_{2}$, and activated carbon-fly ash$\mathrm{nZnO}$ composite materials, respectively.

The result showed that the percentage organic materials present in the activated carbon, fly ash, $\mathrm{nFe}_{3} \mathrm{O}_{4}$, $\mathrm{nSiO}{ }_{2}, \mathrm{nZnO}$, activated carbon-fly ash, activated carbon-fly ash- $\mathrm{nFe}_{3} \mathrm{O}_{4}$, activated carbon-fly ash- $\mathrm{nSiO}_{2}$ and activated carbon-fly ash-nZnO composite materials amount to $99.55 \%$, $2.6 \%, 2.8 \%, 1.7 \%, 0.8 \%, 53.7 \%, 41.5 \%, 38.55 \%$, and $38.1 \%$, respectively. The result obtained in Figure 21 showed that the precursors have higher percentage of inorganic components as compared to the prepared composite materials except for activated carbon. 


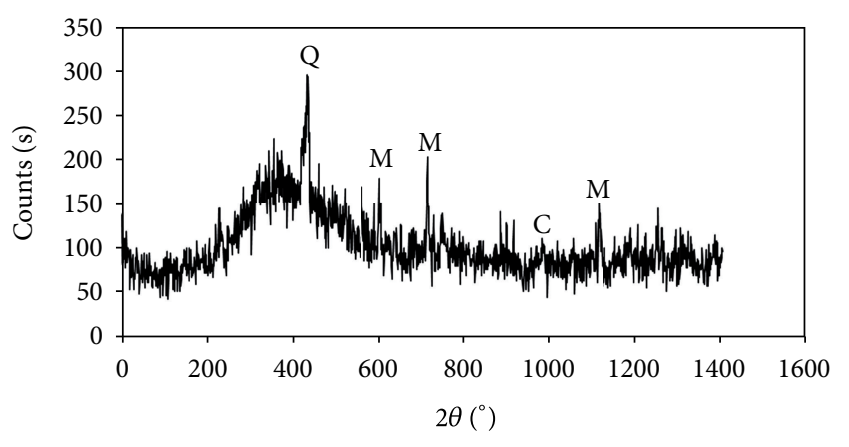

M: Mullite $\left(\mathrm{Al}_{6} \mathrm{Si}_{2} \mathrm{O}_{13}\right)$

Q: Quartz $\left(\mathrm{SiO}_{2}\right)$

C: Cristobalite $\left(\mathrm{SiO}_{2}\right)$

FIGURE 24: X-ray diffraction of activated carbon-fly ash-nSiO ${ }_{2}$ composite material.

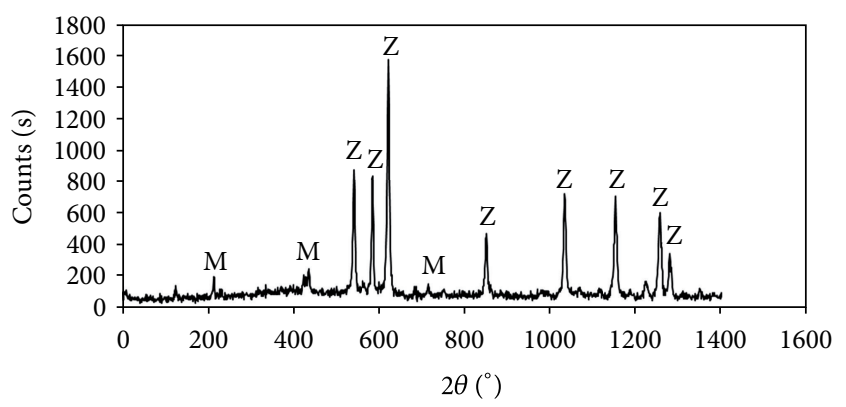

M: Mullite $\left(\mathrm{Al}_{6} \mathrm{Si}_{2} \mathrm{O}_{13}\right)$

Q: Quartz $\left(\mathrm{SiO}_{2}\right)$

Z: Zinc oxide (nZnO)

FIGURE 25: X-ray diffraction of activated carbon-fly ash-nZnO composite material.

3.6. X-Ray Diffraction. The diffractogram of activated carbon shows the absence of crystalline substances, while the fly ash is dominated mainly by crystalline minerals mullite and quartz with large characteristic peaks of quartz $\left(\mathrm{SiO}_{2}\right)$ as reported by Fatoki et al. [22] and Ayanda et al. [23], respectively. The x-ray diffractograms of $\mathrm{nFe}_{3} \mathrm{O}_{4}, \mathrm{nSiO}_{2}$, and $\mathrm{nZnO}$ have also been reported by Fatoki et al. [22].

Figures 22 to 25 thus show the X-ray diffractograms of activated-fly ash, activated carbon-fly ash- $\mathrm{nFe}_{3} \mathrm{O}_{4}$, activated carbon-fly ash- $\mathrm{nSiO}_{2}$, and activated carbon-fly ash-nZnO composite materials.

The diffractogram of activated carbon-fly ash (Figure 22) showed that the crystalline minerals mullite and quartz of fly ash are dominant. The X-ray diffractogram of activated carbon-fly ash- $\mathrm{nFe}_{3} \mathrm{O}_{4}$ composite material (Figure 23) consists of mullite $\left(\mathrm{Al}_{6} \mathrm{Si}_{2} \mathrm{O}_{13}\right)$, quartz $\left(\mathrm{SiO}_{2}\right)$, and magnetite $\left(\mathrm{Fe}_{3} \mathrm{O}_{4}\right)$.

The x-ray diffractogram of activated carbon-fly ash$\mathrm{nSiO}_{2}$ composite material (Figure 24) consists of mullite $\left(\mathrm{Al}_{6} \mathrm{Si}_{2} \mathrm{O}_{13}\right)$, quartz $\left(\mathrm{SiO}_{2}\right)$, and cristobalite $\left(\mathrm{SiO}_{2}\right)$, while the
$\mathrm{X}$-ray diffractogram of activated carbon-fly ash-nZnO composite material (Figure 25) consists of mullite $\left(\mathrm{Al}_{6} \mathrm{Si}_{2} \mathrm{O}_{13}\right)$, quartz $\left(\mathrm{SiO}_{2}\right)$, and zinc oxide (nZnO).

All the diffractograms obtained showed defined characteristic peaks corresponding to the mineral constituents of the precursors and the composite materials. This showed that the precursors and all the prepared composite materials are pure.

3.7. Surface Area and Porosity Determination. Results obtained on the Brunauer, Emmett, and Teller (BET) surface area and porosity determinations of activated carbon-fly ash-nanometal oxide composite materials as well as their precursors are shown in Table 1 and Figure 26.

The surface areas of fly ash, activated carbon, $\mathrm{nFe}_{3} \mathrm{O}_{4}$, $\mathrm{nSiO}_{2}$, and $\mathrm{nZnO}$ are $1.06 \pm 0.003,1156 \pm 8.69,37 \pm 0.19$, $217 \pm 1.76$, and $14 \pm 0.039 \mathrm{~m}^{2} / \mathrm{g}$, respectively, while the surface areas of activated carbon-fly ash, activated carbonfly ash- $\mathrm{nFe}_{3} \mathrm{O}_{4}$, activated carbon-fly ash- $\mathrm{nSiO}_{2}$, and activated carbon-fly ash-nZnO are $5.3 \pm 0.027,299 \pm 1.09,352 \pm$ 1.013 and $240 \pm 1.15$, respectively. The results showed that the use of activated carbon, fly ash, and nanometal oxides for the preparation of activated carbon-fly ash-nanometal oxide composite material greatly improve the surface area of fly ash and nanometal oxides. The surface area of fly ash was therefore improved by $99.65 \%$ for activated carbon-fly ash-nFe $\mathrm{O}_{4}, 99.70 \%$ for activated carbon-fly ash- $\mathrm{nSiO}_{2}$, and $99.56 \%$ for activated carbon-fly ash-nZnO composites, while the surface area of $\mathrm{nFe}_{3} \mathrm{O}_{4}, \mathrm{nSiO}_{2}$, and $\mathrm{nZnO}$ was increased by $87.60 \%, 38.28 \%$, and $94.01 \%$ for the activated carbonfly ash-nFe ${ }_{3} \mathrm{O}_{4}$, activated carbon-fly ash- $\mathrm{nSiO}_{2}$ and activated carbon-fly ash-nZnO composites, respectively.

The micropore area of activated carbon-fly ash- $\mathrm{nFe}_{3} \mathrm{O}_{4}$ was $118.89 \mathrm{~m}^{2} / \mathrm{g}$, activated carbon-fly ash- $\mathrm{nSiO}_{2}$ has a micropore area of $154.21 \mathrm{~m}^{2} / \mathrm{g}$, while activated carbon-fly ash$\mathrm{nZnO}$ micropore area was $82.17 \mathrm{~m}^{2} / \mathrm{g}$. The micropore areas of fly ash, $\mathrm{nFe}_{3} \mathrm{O}_{4}, \mathrm{nSiO}_{2}$ and $\mathrm{nZnO}$ which are $0.38,3.98,16.13$, and $3.18 \mathrm{~m}^{2} / \mathrm{g}$, respectively, and were thus smaller than the micropore areas of the corresponding composite materials. It could therefore be concluded that the composition of activated carbon, nanometal oxide, and fly ash also improved the micropore area of fly ash and nano metal oxides.

3.8. Removal Efficiency of TBT by the Precursors and Composite Materials. The results obtained from TBT removal efficiency of these materials showed that the activated carbon, fly ash, $\mathrm{nFe}_{3} \mathrm{O}_{4}, \mathrm{nSiO}_{2}, \mathrm{nZnO}$ were able to remove $99.3 \%, 94.5 \%$, $81.9 \%, 79.9 \%$, and $92.9 \%$ of the total TBT concentration in artificial seawater, respectively. However, activated carbonfly ash, activated carbon-fly ash- $\mathrm{nFe}_{3} \mathrm{O}_{4}$, activated carbonfly ash- $\mathrm{nSiO}_{2}$, and activated carbon-fly ash-nZnO composite materials removed $99.78 \%, 99.98 \%, 99.97 \%$, and $99.99 \%$ TBT, respectively. The results are illustrated in Figure 27.

It is therefore evident from the results presented in Figure 27 that apart from activated carbon which showed comparable result with the composite materials, all the composite materials exhibited higher ( $>99 \%)$ TBT removal efficiency than their respective precursors. These composite materials 
TABLE 1: BET result of activated carbon-fly ash-nano metal oxide composite materials.

\begin{tabular}{lccccc}
\hline Samples & $\begin{array}{c}\text { BET surface area } \\
\mathrm{m}^{2} / \mathrm{g}\end{array}$ & $\begin{array}{c}\text { Micropore volume } \\
\mathrm{cm}^{3} / \mathrm{g}\end{array}$ & $\begin{array}{c}\text { Micropore area } \\
\mathrm{m}^{2} / \mathrm{g}\end{array}$ & $\begin{array}{c}\text { External surface area } \\
\mathrm{m}^{2} / \mathrm{g}\end{array}$ & $\begin{array}{c}\text { Average pore diameter } \\
\AA\end{array}$ \\
\hline $\mathrm{Ac}$ & $1156 \pm 8.69$ & 0.182 & 442.75 & 713.89 & 48.89 \\
$\mathrm{Fly}$ ash & $1.06 \pm 0.003$ & 0.0001 & 0.38 & 0.68 & 89.43 \\
$\mathrm{nFe}_{3} \mathrm{O}_{4}$ & $37 \pm 0.19$ & 0.002 & 3.98 & 33.19 & 217.42 \\
$\mathrm{nSiO}_{2}$ & $217 \pm 1.76$ & 0.006 & 16.13 & 201.49 & 88.08 \\
$\mathrm{nZnO}$ & $14 \pm 0.039$ & 0.001 & 3.18 & 11.23 & 98.50 \\
$\mathrm{Ac}-\mathrm{fly}$ ash & $5.3 \pm 0.027$ & 0.00002 & 0.19 & 5.11 & 210.01 \\
$\mathrm{Ac}-\mathrm{fly}$ ash- $\mathrm{nFe}_{3} \mathrm{O}_{4}$ & $299 \pm 1.09$ & 0.048 & 118.89 & 180.86 & 63.55 \\
Ac-fly ash-nSiO & $352 \pm 1.013$ & 0.063 & 154.21 & 198.41 & 64.78 \\
Ac-fly ash-nZnO & $240 \pm 1.15$ & 0.033 & 82.17 & 158.64 & 51.84 \\
\hline
\end{tabular}

Ac: Activated carbon.

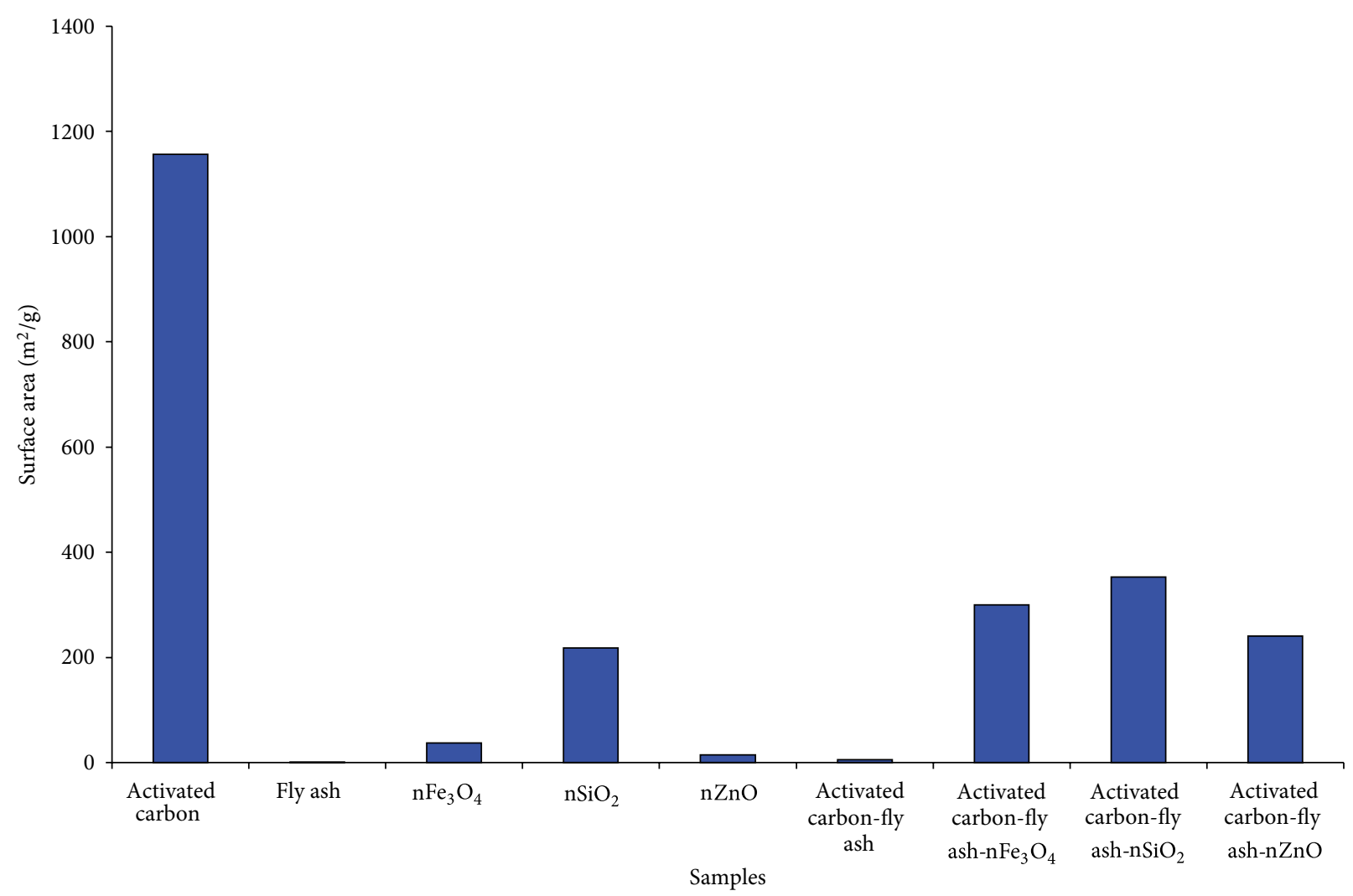

FIGURE 26: Surface area $\left(\mathrm{m}^{2} / \mathrm{g}\right)$ versus precursors and activated carbon-fly ash-nanometal oxide composite materials.

are therefore potentially good materials for remediation application of TBT laden wastewater.

\section{Conclusion}

Experimental results showed that the $\mathrm{pH}$ values of activated carbon, $\mathrm{nSiO}_{2}$, activated carbon-fly ash, activated carbon-fly ash- $\mathrm{nFe}_{3} \mathrm{O}_{4}$, activated carbon-fly ash-nSiO${ }_{2}$, and activated carbon-fly ash-nZnO are negatively charged and will therefore be suitable for the sorption of cationic complexes, while the $\mathrm{pH}$ values of fly ash, $\mathrm{nFe}_{3} \mathrm{O}_{4}$, and $\mathrm{nZnO}$ are slightly lower than their corresponding PZC values which suggest that their surfaces are positively charged and will therefore be favourable to the sorption of anionic complexes and heavy metals. The ash content determination also showed that the level of inorganic materials present in the adsorbent composite materials is a function of the precursors that make up the composite materials. The XRD and FTIR analyses confirmed the absence of impurity in the precursors and the prepared composite materials. The results of BET surface 


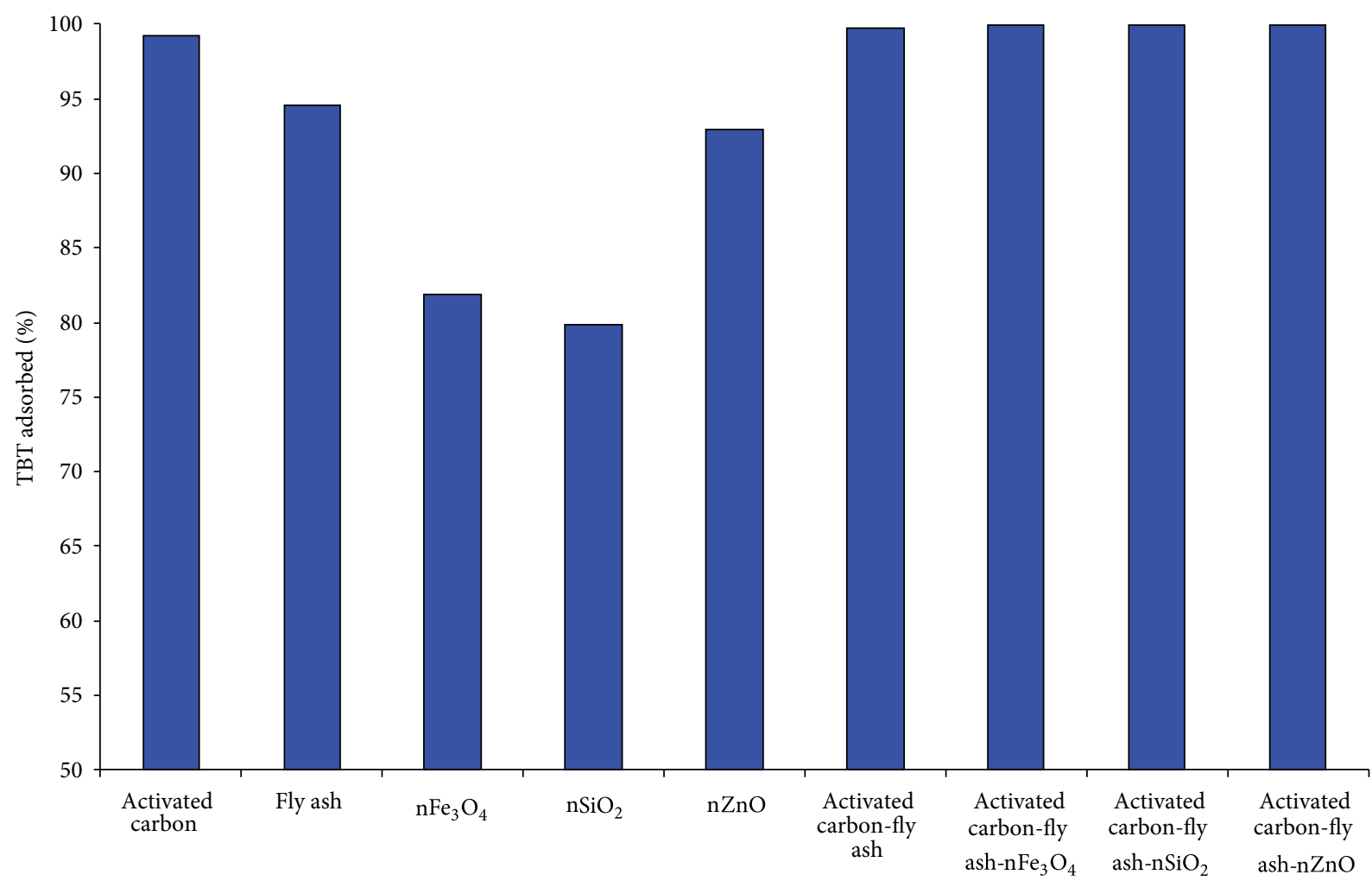

Samples

FIGURE 27: Removal efficiency of TBT by the precursors and composite materials. Experimental conditions: concentration of TBT = 100 ppm; $\mathrm{pH}=8$; volume of TBT solution $=25 \mathrm{~mL}$; mass of activated carbon $=0.5 \mathrm{~g}$; contact time $=60 \mathrm{~min}$; stirring speed $=200 \mathrm{rpm}$; temperature $=$ $22^{\circ} \mathrm{C}$.

area and porosity determination also supported the higher sorption of TBT by the composite materials. The compositing of activated carbon, nanometal oxides, and fly ash increased the surface area and micropore area of fly ash and nano metal oxides which resulted in higher sorption capacity of the composite materials than their precursors.

\section{Acknowledgments}

O. S. Ayanda wishes to thank Cape Peninsula University of Technology, Cape Town, South Africa for the award of 2011 and 2012 bursary to study D. Tech. Chemistry in the institution. The author also thanks Professor L. Petrik and Dr. O. Fatoba (Department of Chemistry, University of Western Cape, South Africa) for providing the Matla fly ash.

\section{References}

[1] M. Ahmaruzzaman, "A review on the utilization of fly ash," Progress in Energy and Combustion Science, vol. 36, no. 3, pp. 327-363, 2010.

[2] G. Q. Lu and D. D. Do, "Adsorption properties of fly ash particles for NOx removal from flue gases," Fuel Processing Technology, vol. 27, no. 1, pp. 95-107, 1991.

[3] K. K. Panday, G. Prasad, and V. N. Singh, "Copper(II) removal from aqueous solutions by fly ash," Water Research, vol. 19, no. 7, pp. 869-873, 1985.
[4] P. Ricou, I. Lécuyer, and P. L. Cloirec, "Removal of $\mathrm{Cu}^{2+}, \mathrm{Zn}^{2+}$ and $\mathrm{Pb}^{2+}$ adsorption onto fly ash and fly ash/lime mixing," Water Science and Technology, vol. 39, no. 10-11, pp. 239-247, 1999.

[5] P. Ricou-Hoeffer, I. Lecuyer, and P. L. Cloirec, "Experimental design methodology applied to adsorption of metallic ions onto fly ash," Water Research, vol. 35, no. 4, pp. 965-976, 2001.

[6] M. Nascimento, P. S. M. Soares, and V. P. D. Souza, "Adsorption of heavy metal cations using coal fly ash modified by hydrothermal method," Fuel, vol. 88, no. 9, pp. 1714-1719, 2009.

[7] I. D. Mall, V. C. Srivastava, and N. K. Agarwal, "Removal of Orange-G and Methyl Violet dyes by adsorption onto bagasse fly ash - Kinetic study and equilibrium isotherm analyses," Dyes and Pigments, vol. 69, no. 3, pp. 210-223, 2006.

[8] S. Wang and $\mathrm{H}$. Wu, "Environmental-benign utilisation of fly ash as low-cost adsorbents," Journal of Hazardous Materials, vol. 136, no. 3, pp. 482-501, 2006.

[9] S. Wang, Q. Ma, and Z. H. Zhu, "Characteristics of coal fly ash and adsorption application," Fuel, vol. 87, no. 15-16, pp. 3469-3473, 2008.

[10] G. Zhang, J. Qu, H. Liu, A. T. Cooper, and R. Wu, " $\mathrm{CuFe}_{2} \mathrm{O}_{4}$ /activated carbon composite: a novel magnetic adsorbent for the removal of acid orange II and catalytic regeneration," Chemosphere, vol. 68, no. 6, pp. 1058-1066, 2007.

[11] L. Li, P. A. Quinlivan, and D. R. U. Knappe, "Effects of activated carbon surface chemistry and pore structure on the adsorption of organic contaminants from aqueous solution," Carbon, vol. 40, no. 12, pp. 2085-2100, 2002. 
[12] M. H. Stenzel, "Remove organics by activated carbon adsorption," Chemical Engineering Progress, vol. 89, no. 4, pp. 36-43, 1993.

[13] G. Newcombe, J. Morrison, C. Hepplewhite, and D. R. U. Knappe, "Simultaneous adsorption of MIB and NOM onto activated carbon II. Competitive effects," Carbon, vol. 40, no. 12, pp. 2147-2156, 2002.

[14] P. R. Shukla, S. Wang, H. M. Ang, and M. O. Tadé, "Synthesis, characterisation, and adsorption evaluation of carbon-naturalzeolite composites," Advanced Powder Technology, vol. 20, no. 3, pp. 245-250, 2009.

[15] C. T. Hsieh and H. Teng, "Langmuir and dubinin-radushkevich analyses on equilibrium adsorption of activated carbon fabrics in aqueous solutions," Journal of Chemical Technology and Biotechnology, vol. 75, no. 11, pp. 1066-1072, 2000.

[16] H. H. Tseng, J. G. Su, and C. Liang, "Synthesis of granular activated carbon/zero valent iron composites for simultaneous adsorption/dechlorination of trichloroethylene," Journal of Hazardous Materials, vol. 192, no. 2, pp. 500-506, 2011.

[17] V. K. Jha, M. Matsuda, and M. Miyake, "Sorption properties of the activated carbon-zeolite composite prepared from coal fly ash for $\mathrm{Ni}^{2+}, \mathrm{Cu}^{2+}, \mathrm{Cd}^{2+}$ and $\mathrm{Pb}^{2+}$, Journal of Hazardous Materials, vol. 160, no. 1, pp. 148-153, 2008.

[18] Z. Sarbak and M. Kramer-Wachowiak, "Porous structure of waste fly ashes and their chemical modifications," Powder Technology, vol. 123, no. 1, pp. 53-58, 2002.

[19] C. Y. Yin, M. K. Aroua, and W. M. A. W. Daud, "Review of modifications of activated carbon for enhancing contaminant uptakes from aqueous solutions," Separation and Purification Technology, vol. 52, no. 3, pp. 403-415, 2007.

[20] G. G. Stavropoulos, P. Samaras, and G. P. Sakellaropoulos, "Effect of activated carbons modification on porosity, surface structure and phenol adsorption," Journal of Hazardous Materials, vol. 151, no. 2-3, pp. 414-421, 2008.

[21] P. Pengthamkeerati, T. Satapanajaru, and P. Chularuengoaksorn, "Chemical modification of coal fly ash for the removal of phosphate from aqueous solution," Fuel, vol. 87, no. 12, pp. 2469-2476, 2008.

[22] O. S. Fatoki, O. S. Ayanda, F. A. Adekola, B. J. Ximba, and B. O. Opeolu, "Preparation and Characterization of Activated carbon $-\mathrm{nFe}_{3} \mathrm{O}_{4}$, Activated carbon $-\mathrm{nSiO}_{2}$ and Activated carbon-nZnO Hybrid Materials," Particle \& Particle Systems Characterization, vol. 29, no. 3, pp. 178-191, 2012.

[23] O. S. Ayanda, O. S. Fatoki, F. A. Adekola, and B. J. Ximba, "Characterization of fly ash generated from matla power station in mpumalanga, South Africa," E-Journal of Chemistry, vol. 9, no. 4, pp. 1788-1795, 2012.

[24] P. Westerhoff, T. Karanfil, and J. Crittenden, Aerogel and Iron-Oxide Impregnated Granular Activated Carbon Media For Arsenic Removal, Awwa Research Foundation and Arsenic Water Technology Partnership, Denver, Colo, USA, 2006.

[25] F. Adekola, M. Fédoroff, H. Geckeis et al., "Characterization of acid-base properties of two gibbsite samples in the context of literature results," Journal of Colloid and Interface Science, vol. 354, no. 1, pp. 306-317, 2011.

[26] J. G. Collin, A. Bono, D. Krishnaiah, and K. O. Soon, "Sorption studies of methylene blue dye in aqueous solution by optimised carbon prepared from guava seeds (Psidium guajava L.)," Materials Science, vol. 13, no. 1, pp. 83-87, 2007.

[27] S. Mopoung and W. Nogklai, "Chemical and surface properties of longan seed activated charcoal," International Journal of Physical Sciences, vol. 3, no. 10, pp. 234-239, 2008.
[28] A. Beganskienè, V. Sirutkaitis, M. Kurtinaitienè, R. Juškènas, and A. Kareiva, "FTIR, TEM and NMR investigations of stöber silica nanoparticles," Journal of Materials Science, vol. 10, pp. 287-290, 2004. 

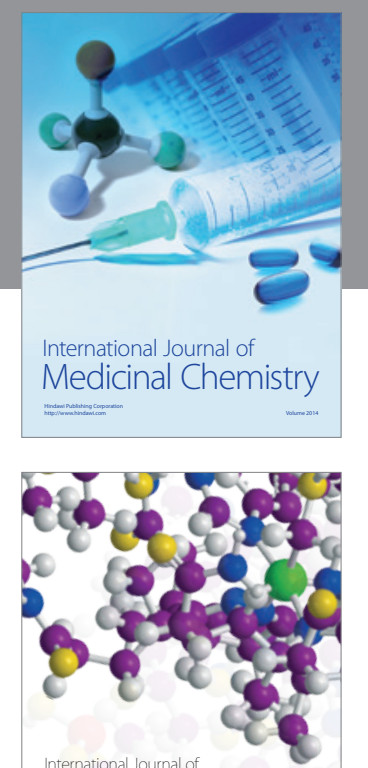

\section{Carbohydrate} Chemistry

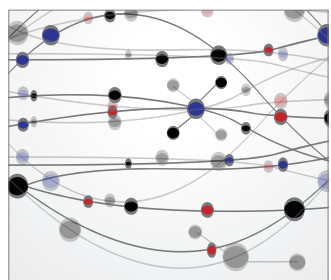

The Scientific World Journal
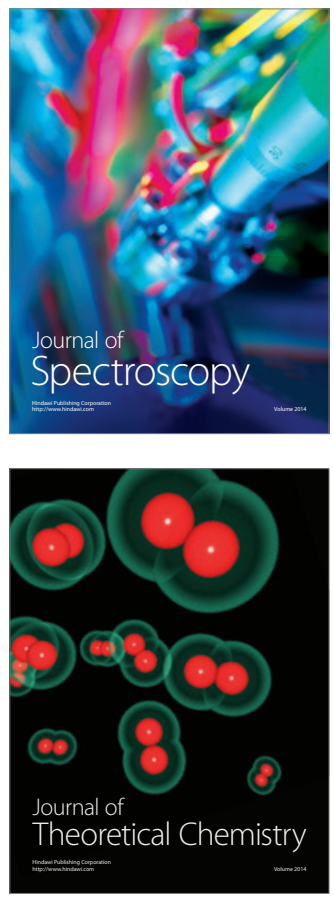
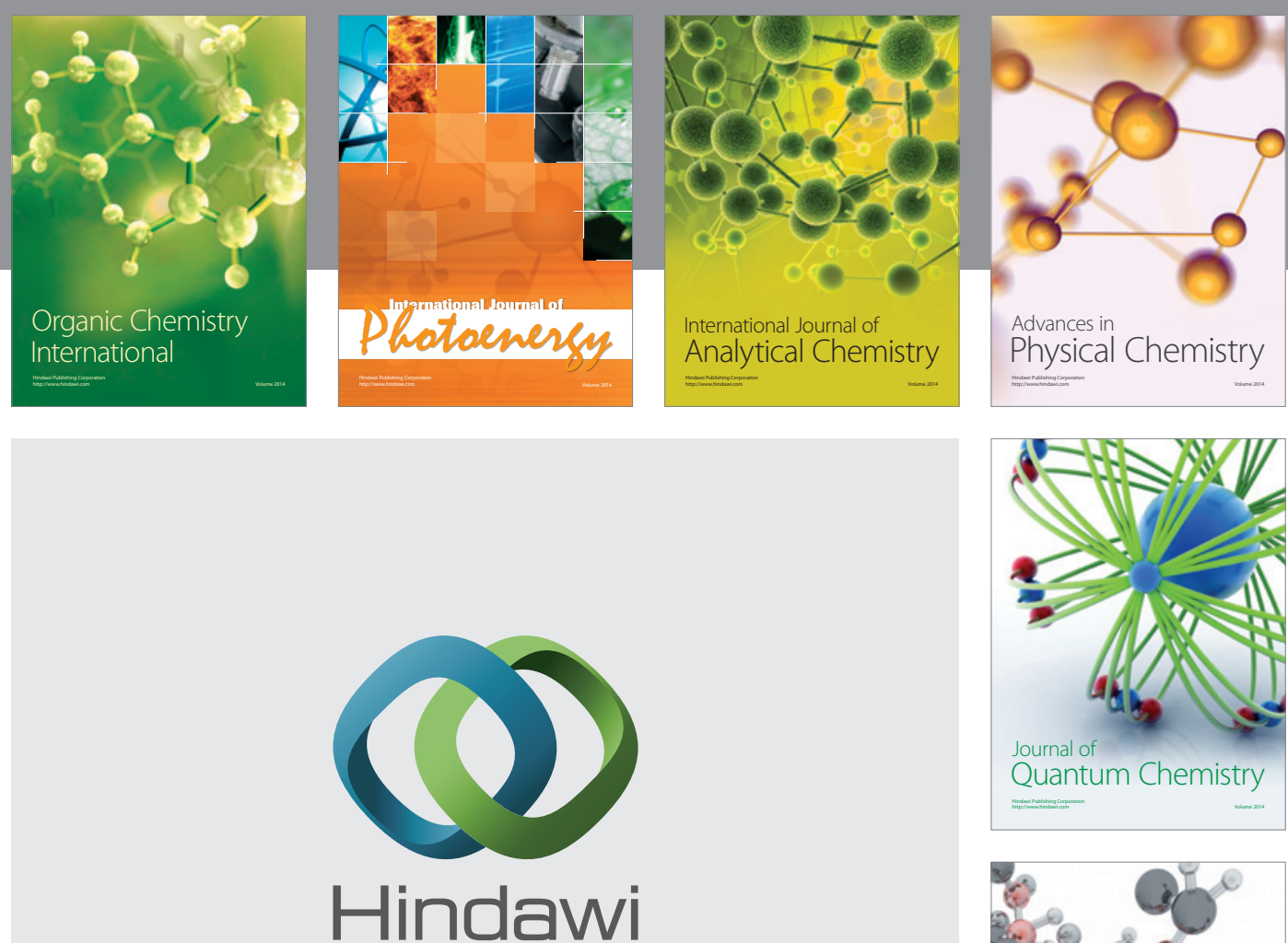

Submit your manuscripts at

http://www.hindawi.com

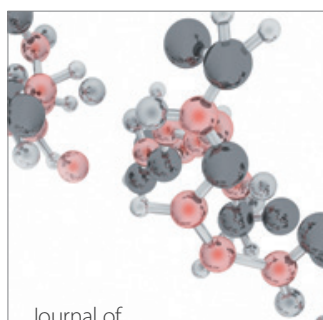

Analytical Methods

in Chemistry

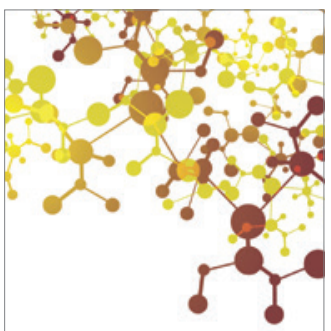

Journal of

Applied Chemistry

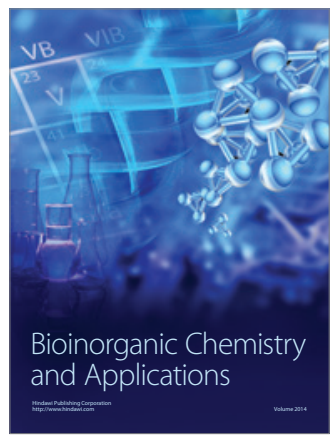

Inorganic Chemistry
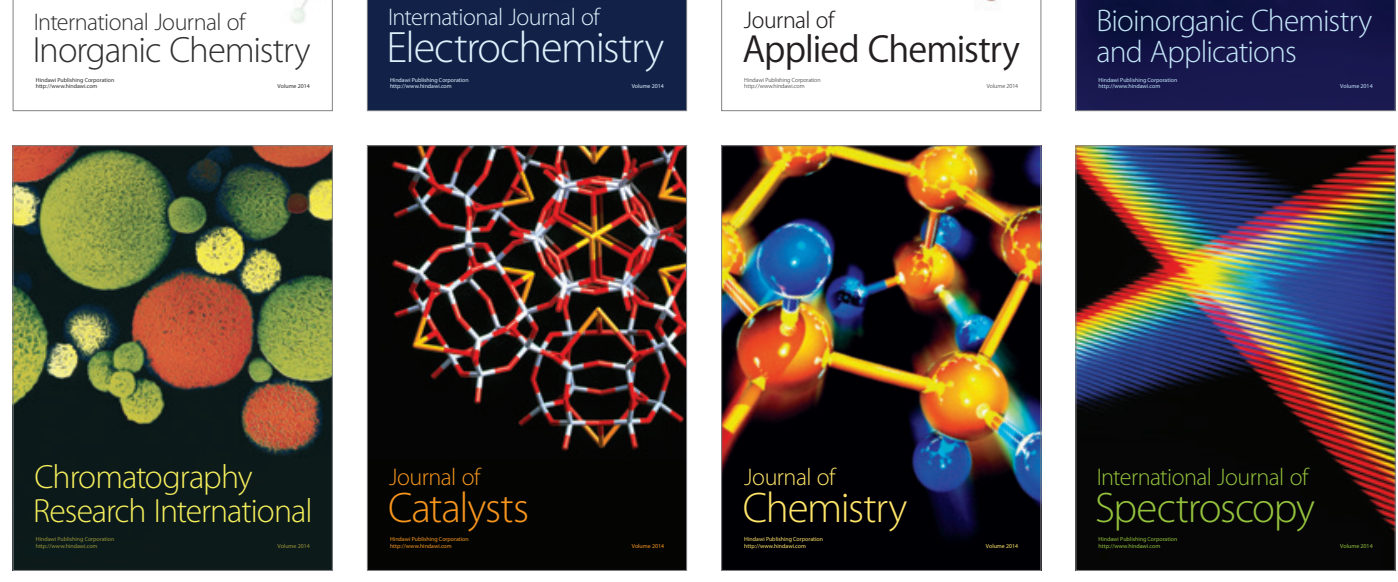